\title{
ACTA ALEXANDRINORUM: QUESTIONAMENTO DOS ALEXANDRINOS ÀS PRATICAS IMPERIAIS ROMANAS
}

Joana Campos Clímaco

Universidade de São Paulo

\begin{abstract}
Resumo
O objetivo do presente artigo é realçar o cenário de crítica e questionamento ao poder romano presente numa documentação intitulada pelos seus editores de Acta Alexandrinorum. Através da análise de algumas temáticas comuns dos escritos selecionados, a principal intenção do artigo é investigar a motivação para a escrita dos textos que foram divulgados como uma espécie de resistência literária dos alexandrinos ao Império nos séculos II e III d.C.
\end{abstract}

\section{Pallavras-chave}

Alexandria • Império romano • Egito romano.

\section{Abstract}

The aim of this article is to illustrate the context of criticism and questioning towards the roman power in a documentation named by its editors as Acta Alexandrinorum. Through the analyses of common themes present in the selected texts, the main idea of is to investigate the initial motivation for the writing of the texts, that were spread as a kind of literary resistance of the Alexandrians towards the Empire in the II and III centuries.

\section{Keywords}

Alexandria $\bullet$ Roman empire $\bullet$ Roman Egypt.

\footnotetext{
${ }^{1}$ A autora é doutoranda da USP e esse artigo é uma parte reformulada de sua dissertação de mestrado que foi financiado pela Fapesp e concluído em 2007.
} 
Dez anos depois de sua fundação por Alexandre o Grande, em 331 a.C., Alexandria tornou-se capital do Egito (substituindo a então capital Mênfis), além de sede da dinastia ptolomaica. Sua fundação e estruturação por uma dinastia macedônia que concedeu à cidade algumas instituições tipicamente gregas, a caracterizam como uma espécie de cidade-estado dentro do Egito. A cidade foi organizada no sistema grego de tribos e demos e possuía diversos órgãos caracteristicamente helênicos, como o ginásio, a efebeia, banhos, teatros, uma assembleia e gerousia. Provavelmente também tinha recebido uma boulé dos Ptolomeus que, por algum motivo, foi perdida. Tais instituições lhe concediam relativa autonomia cívica e a cultura grega também se manifestava em tradições e em diversos níveis do cotidiano. ${ }^{2}$ No entanto, a força da tradição egípcia mais antiga também estava ali presente, representada pela população nativa. Mesmo sendo o setor da população de menor status social, era o mais numeroso no contexto de fundação da cidade. ${ }^{3}$ Harold Bell acredita que, mesmo geograficamente fazendo parte do território egípcio, na maior parte das fontes

\footnotetext{
${ }^{2}$ Alguns autores enfatizam o status de Alexandria como uma espécie de pólis, devido à presença dessas instituições. Ver: JONES, Stuart. Claudius and the Jewish question at Alexandria. Journal of Roman Studies, 16, 1926, p. 28. Diana Delia ressalta a semelhança das instituições alexandrinas e atenienses e acredita que não se trata apenas de uma comparação superficial, pois tais órgãos tinham realmente sido fundados tendo Atenas como modelo. DELIA, Diana. Alexandria citizenship during the Roman Principate. Atlanta: Scholars Press, 1991, p. 5. Peter Fraser argumenta que sobretudo a cidade fundada por Alexandre não poderia ter sido desprovida dessas instituições democráticas. O autor salienta que alguns elementos do "código civil alexandrino" realmente derivavam do ateniense, mas destaca que "o elemento Ático era apenas um dentre diversos no código, e também não era predominante" e já englobava a diversidade cultural do mundo grego. FRASER, Peter M. Ptolemaic Alexandria I-III. Oxford: Clarendon Press, 1972, p. 93-94.

${ }^{3}$ Com relação à política dos Ptolomeus destinada à população egípcia nativa, inúmeras são as discordâncias historiográficas. Antes de tudo, deve-se destacar que os Ptolomeus encontraram formas muito diferentes para se relacionar, internamente, com os cidadãos e habitantes alexandrinos e, externamente, com os egípcios e habitantes da Chora e das outras cidades não-gregas. Aqui nos centraremos no modo como as políticas destinadas à população egípcia repercutiram em Alexandria, já que os egípcios representavam um segmento significativo da cidade. Dessa forma, os Ptolomeus tiveram que aceitar e estimular algumas das antigas tradições nativas e destinar aos egípcios uma política conciliatória para que seu poder fosse aceito e legitimado. Assim, alguns elementos da cultura faraônica milenar foram respeitados e inclusive muitos de seus componentes "adotados" pelos reis para que fossem recebidos na região. Harold Bell argumenta que os últimos Ptolomeus, pela decadência da dinastia e crescente dependência dos romanos, sentiram a necessidade de aliar-se aos sacerdotes egípcios. Com isso, tiveram que "egipcianizar a monarquia" e reforçar alguns elementos dessa cultura. Ver: BELL, Harold I. Egypt from Alexander the Great to the Arab conquest. Oxford: Claredon Press, 1948, p. 60. John Marlowe desenvolve com ainda mais ênfase o que ele chama da tal "egipcianização" da dinastia; ver: MARLOWE, John. The Golden Age of Alexandria. London: Victor Gollancz, 1971, p. 110.
} 
da época observa-se grande contraste entre a Alexandria e o Egito, sugerindo que, oficialmente, a cidade era considerada independente. ${ }^{4}$

Alexandria alcançou desde cedo grande destaque econômico, pela sua posição estratégica e cultural. Tornou-se, portanto, um centro atrativo para populações das mais diversas proveniências e com as mais diferentes pretensões. Ou seja, sua construção foi algo de impacto para o Egito e para o Mediterrâneo como um todo e o afluxo de diferentes povos para a cidade desde sua fundação foi intenso e estimulado pelos Ptolomeus. ${ }^{5}$ Assim, a composição populacional de Alexandria era variada e cosmopolita. Além disso, a cidade era a sede de uma monarquia, ou seja, fortes elementos que esvaziam a sua caracterização como uma cidade-estado grega e enfraquecem sua existência autônoma. ${ }^{6}$

Com a derrota de Cleópatra e Marco Antônio, em 31 a.C., por Augusto, a era ptolomaica chega ao fim e Alexandria entra decisivamente na esfera de influência imperial, tornando-se a capital da província romana do Egito. Com a ascensão da potência romana, a cidade era a segunda maior e mais populosa do Mediterrâneo, além de capital do Egito, último grande reino conquistado pelo Império. A sua vivência cultural era valiosa pelo ambiente de estudos criado no Museu e na Biblioteca e que fez da cidade um ponto de união entre homens letrados de diversas regiões. ${ }^{7}$ Economicamente, Alexandria era também crucial naquele universo,

\footnotetext{
${ }^{4}$ BELL, Harold I. Alexandria ad Aegyptum. The Journal of Roman Studies, 36, 1946, p. 132. Naphtali Lewis defende que a localização da cidade no litoral foi algo proposital, para que ela fosse considerada parte do mundo grego e não do Egito. Ver: LEWIS, Naphtali. Greeks in Ptolomaic Egypt: Case studies in the social history of the Hellenistic world. Oakville, Connecticut: American Society of Papyrologists, 2001. Alan Bowman caracteriza a cidade como um "corpo estranho" no Egito. BOWMAN, Alan. Egypt after the Pharaos 332 B.C. - A.D. 642. California: University of California Press, 1986, p. 204.

${ }^{5}$ Peter Fraser dividiu a formação inicial da cidade em sete categorias: primeiramente, a população grega que consistia nos cidadãos, cidadãos parciais (cujo status exato é obscuro), gregos sem status civil definido, gregos com vínculos étnicos externos; e a população não-grega, que consistia da população egípcia nativa, imigrantes não-gregos (judeus, habitantes da Síria e outros) e escravos. Os macedônios (cuja importância foi superestimada pela historiografia, segundo o autor) permaneceram mais restritos ao círculo militar da guarda real e poucos entraram na administração civil ptolomaica. FRASER, Peter M., op. cit., 1972, p. 38-53. El-Abbadi salienta que, antes do meio do séc. II a.C., os descendentes dos gregos ainda podiam ser identificados e os Ptolomeus tentariam mantê-los "o mais puros de sangue" possível. Porém, já no início do séc. II, os ditos gregos já não o eram por origem, mas helenizados. Ver: EL-ABBADI, Mostafa. The Alexandrian citizenship. Journal of Egyptian Archaeology, 48, 1962, p. 114.

${ }^{6}$ DAVIS, Simon. Race-relations in Ancient Egypt: Greek, Egyptian, Hebrew, Roman. London: Methuen \& Co., 1951, p. 48.

${ }^{7}$ Através da compra de manuscritos originais ou do empréstimo para a produção de cópias, concentrou-se ali não só toda a produção grega, mas também a tradução para o grego da literatura de
} 
pois além da intensidade das transações comerciais realizadas em seu porto, a importância do Egito como maior exportador de trigo para o Império era bem lembrada pelos romanos. Sua posição no litoral mediterrâneo e as várias saídas para o Nilo permitiam uma forte movimentação comercial dentro e fora do Egito.

Além da mencionada importância de Alexandria para os romanos, no final do período ptolomaico, a cidade começou ser vista como uma ameaça política aos interesses imperiais. Assim, os líderes romanos pouco a pouco lhe destinam olhares cuidadosos. Antes de vencer Marco Antônio e Cleópatra, corriam rumores de que a cidade estava rivalizando com Roma e tornar-se-ia capital do "mundo". ${ }^{8}$ Essa foi uma das razões que ajudou Augusto a se tornar popular entre os romanos e vencer Marco Antônio. A relação deste com Cleópatra e o crescente prestígio da rainha no Oriente teriam criado uma espécie de rejeição a eles entre os romanos, pois se acreditava que o poder do Egito simbolizava uma ameaça ao desenvolvimento e expansão do Império, que deveria sempre ter Roma como sede. ${ }^{9}$ Em suma: Alexandria intimidava as pretensões romanas por representar uma ameaça aos seus projetos e, ao mesmo tempo, era parte de uma região de valor fundamental para o Império.

Enfatiza-se muito na historiografia a peculiaridade do Egito e sua importância para os romanos, o que fez Augusto lhe destinar uma política especial e distinta das aplicadas às outras províncias. ${ }^{10}$ Outra especificidade do Egito era o

outros povos. Arnaldo Momigliano ressalta, contudo, que os habitantes locais de regiões não-gregas, sendo bilíngues, tiveram então a oportunidade de explicar suas culturas em grego para os gregos. Assim, poderiam “ajustar" determinadas informações a respeito de suas crenças, em relação ao que queriam propagar, e ocultar outras. Os gregos, por outro lado, não tinham condições de verificar tais informações, já que não conheciam as línguas nativas desses povos. MOMIGLIANO, Arnaldo. Os limites da helenização: A interação cultural das civilizações grega, romana, céltica, judaica e persa. Rio de Janeiro: Jorge Zahar, 1991, p. 14-16. Nunca se tinha concentrado, em um só local, e em tão grande escala, os escritos dos homens e, além disso, trabalhado para que ficassem para a posteridade. Christian Jacob e François de Polignac consideram que a ambição dos Ptolomeus era aliar poder e cultura em um só local. Nesse sentido, mesmo que de modo diferente de Roma, a cidade também tinha pretensões de se tornar uma "metrópole universal". JACOB, Christian; POLIGNAC, François de. The Alexandrian mirage. In: Idem (eds.). Alexandria, third century B.C.: The knowledge of the world in a single city. Alexandria: Harpocrates Publishing, 2000, p. 17-18. ${ }^{8}$ GRIMAL, Pierre. O Império romano. Lisboa: Edições 70, 1993, p. 47.

${ }^{9}$ ROSTOVTZEFF, Michael I. Historia social y económica del Império romano. Tomo I. Madrid: Espasa-Calpe, S.A., 1937, p. 103.

${ }^{10}$ Temos, contudo, que ser cautelosos em simplesmente definir o Egito como uma província que teria recebido um tratamento especial do imperador, como Alan Bowman enfatiza no seu livro Egypt after the Pharaos. Ver: BOWMAN, Alan, op. cit., 1986. A documentação abundante do território, referente, sobretudo, ao período greco-romano, nos permite acessar esferas de sua vida social, cul- 
respeito imposto pela grandeza, riqueza e força de sua cultura milenar que provocava nos antigos um misto de encanto e estranhamento. A "força" do território e o destaque de Alexandria foram muito considerados por Augusto ao estabelecer o domínio. ${ }^{11}$ Por todas as questões realçadas acima, temia que pudesse despertar no Egito, e principalmente em Alexandria, algum foco de oposição ao Império, por ainda haver na cidade muitos partidários de seu antigo rival. Em virtude desse receio, a base do poder romano no Egito foi estruturada em Alexandria. ${ }^{12}$

Augusto pensou um sistema que funcionaria de forma a nunca deixar um único indivíduo, além do imperador, com muito poder, e os oficiais deveriam lhe prestar contas com grande frequência. ${ }^{13}$ A política de nomear um prefeito e não permitir a entrada de senadores foi uma estratégia de Augusto para manter o controle mais cerrado da província. ${ }^{14}$ Instalou também no território três legiões permanentes do exército, algo também destinado especialmente ao Egito. No que se refere à autonomia de Alexandria para questões locais, a questão é controversa. A discussão a respeito da Boulé é um dos pontos de mais discórdia entre os comentadores. A polêmica se refere ao momento preciso em que Alexandria recebeu uma Boulé, e quais foram os motivos de sua perda. Tendo ou não sido suprimida por Augusto, o que se sabe é que a instituição só foi novamente estabelecida por Severo em 200/201 d.C., juntamente com outras mudanças administrativas realizadas no Egito. ${ }^{15}$

tural e política em escala não comparável às outras províncias. Maurice Sartre acredita que grande parte da peculiaridade que comumente define o Egito é vinculada à quantidade de documentação de lá disponível, possibilitando um maior conhecimento de suas instituições. SARTRE, Maurice. El Oriente romano: Provincias y sociedades provinciales del Mediterráneo oriental. De Augusto a los Severos (31 a.C. - 235 d.C.). Madrid: Akal Ediciones, 1994, p. 442. Em contraste com a concepção de Bowman, Roger Bagnall considera que podemos sim usar muitas informações disponíveis a respeito do Egito para compreender práticas mais gerais da política imperial. BAGNALL, Roger. Reading papyri, writing ancient history. London; New York: Routledge, 1995, p. 66 e 117.

${ }^{11}$ SARTRE, Maurice, op. cit., 1994, p. 442.

${ }^{12}$ Vários autores detalham essa situação peculiar da cidade: Ver: MILNE, Grafton. A history of Egypt under Roman rule. London: Methuen \& Co., 1924, p. 120-121. SARTRE, Maurice, op. cit., 1994, p. 456; BOWMAN, Alan; RATHBONE, Dominic. Cities and administration in Roman Egypt. Journal of Roman Studies, 82, 1992, p. 110; GOODMAN, Martin. The Roman world. 44 B.C. - A.D. 180. London; New York: Routledge, 1997, p. 265.

${ }^{13}$ GOODMAN, Martin, op. cit., 1997, p. 109. Peter Brunt ressalta as especificidades do cargo criado para o Egito. Ver: BRUNT, Peter A. The administrators of Roman Egypt. The Journal of Roman Studies, 65, 1975, p. 128-129.

${ }^{14}$ BOWMAN, Alan, op. cit., 1986, p. 38.

${ }^{15}$ A opinião mais geral entre os historiadores é que, na fundação de Alexandria, a cidade teria recebido a boulé de Alexandre e a teria perdido posteriormente ainda no período ptolomaico, apesar 
Além das inovações no complexo burocrático, uma das mais significativas mudanças introduzidas pelos romanos se refere às novas definições de status destinadas à população. Foram estabelecidas novas categorias que repercutiram diretamente na cobrança de impostos, das quais os cidadãos alexandrinos eram os únicos isentos. Mas, para obter a cidadania, teria que se provar a ascendência helenizada de ambos os lados, materno e paterno. Os não-gregos, egípcios e estrangeiros de territórios não helenizados eram considerados os habitantes de menor status e, consequentemente, estavam sujeitos às maiores cobranças (apesar da obtenção da cidadania por uma minoria). Eram considerados egípcios todos os elementos provenientes da Chora e de outras regiões do Egito. A comunidade judaica era a maior da diáspora, substancialmente helenizada e muito influente na cidade, chegando a representar quase $1 / 3$ de sua população local. Mas na delimitação de status, os judeus também receberam maiores cobranças que os habitantes de origem helênica, o que os deixou num patamar aproximado ao dos egípcios e foi considerado por eles como maior motivo de insatisfação frente ao poderio imperial e aos vizinhos alexandrinos. Em virtude do grau de helenização de muitos judeus, alguns começaram a exigir dos romanos menores cobranças (tentando se igualar ao status dos cidadãos alexandrinos). Dessa forma, conseguem algumas concessões, o que lentamente vai desagradando os alexandrinos que vão reclamar aos romanos a superioridade de seu grupo social em relação à comunidade judaica. Ou seja, intensificam-se os conflitos por status entre a população culturalmente difusa de Alexandria, principalmente entre alexandrinos e judeus, por estes estarem conquistando privilégios antes restritos àqueles.

Devemos observar, ainda, que nenhuma das categorias sociais aqui definidas era homogênea e que a assimilação e aproximação entre as diversas culturas ocorriam em todos os momentos, apesar da criação de "barreiras" entre elas (algumas permanentes e outras mais flexíveis de acordo com as circunstâncias). Gregos e judeus, por exemplo, identificavam-se linguisticamente, já que o grego era a língua oficial dos dois grupos, no entanto, cultural e religiosamente muito se distinguiam. Egípcios e gregos, por outro lado, tinham uma religiosidade mais "conciliável" e puderam ajustar suas crenças em algumas ocasiões e criar cultos comuns. Nesse sentido, apesar de alguns elementos das duas tradições

de não se saber sobre o motivo da perda. DAVIS, Simon, op. cit., 1951, p. 61; BOWMAN, Alan, op. cit., 1986, p. 211; MILNE, Grafton, op. cit., 1924, p. 282; BELL, Harold. The problem of the Alexandrian Senate. Aegyptus, 12, 1932, p. 184. 
religiosas causarem estranhamento mútuo, no geral, eles não eram significativos a ponto de impedir a tolerância na vivência diária de seus grupos.

A peculiaridade do judaísmo em relação aos gregos e egípcios deve-se ao seu corpo de leis e doutrinas que fazia com que o fiel tivesse obrigatoriamente uma rotina diferente de toda a população da cidade, já que suas crenças incidiam diretamente sobre o seu comportamento diário. Apesar da tentativa de separação de outros grupos, Collins argumenta que, sobretudo para os judeus mais eruditos e das classes abastadas, a inserção na cultura helênica era antes de tudo uma questão de "sobrevivência". Assim, continuavam a praticar a fé antiga, mas de forma que facilitasse a convivência com estrangeiros. Ou seja, renunciavam a algumas práticas que os isolavam e os separavam dos não-judeus (como a observância do sábado e a circuncisão) e reafirmavam outras que legitimassem sua fé diante dos gentios e que a transformassem em algo simpático ou ao menos indiferente a estes. ${ }^{16}$ John Barclay considera que a correta observância das leis era o que mantinha a comunidade judaica unida e o que mais tornava seu modo de vida distinto da comunidade dos gentios, apesar de em determinados momentos fazerem um uso menos rígido das mesmas. ${ }^{17}$

Apesar das queixas dos judeus, no que se refere ao pagamento de impostos, os imperadores romanos, como os Ptolomeus anteriores, permitiam que eles vivessem de acordo com suas leis e costumes antigos. Nos principados de Augusto e Tibério, a situação foi relativamente tranquila, mas com Calígula os problemas se intensificaram, pois ele ameaçou a continuidade da observância da fé judaica. Os alexandrinos aproveitaram-se da oposição do imperador para também manifestar suas insatisfações contra o grupo. Ocorreu então, em 38, o primeiro conflito aberto entre os grupos. Fílon descreve a polêmica como um "ataque" dos gregos sobre os judeus que teriam sido as completas vítimas da situação. ${ }^{18}$

\footnotetext{
${ }^{16}$ COLLINS, John J. Between Athens and Jerusalem: Jewish identity in the Hellenistic Diaspora. Michigan: Eerdmans, 2000, p. 169.

${ }^{17}$ BARCLAY, John. Jews in the Mediterranean Diaspora: From Alexander to Trajan (323 B.C.E. - 117 C.E.). Berkeley; Los Angeles; London: University of California Press, 1996, p. 426.

${ }^{18}$ Fílon relata detalhadamente as violências de que os judeus foram vítimas. Além do desrespeito ao templo, a população alexandrina também protestava contra o direito judaico de obtenção da cidadania e da participação política, além de os proclamarem estrangeiros no território egípcio (FILON. In Flaccum 55-57). A partir daí, episódios de conflitos ocorreram com grande frequência, e os protagonistas foram geralmente os dois grupos, alexandrinos e judeus. No ano em que assumiu o Império, Cláudio escreveu uma carta aos alexandrinos com o objetivo de colocar um fim às turbulências de maneira diferente de seu antecessor, tentando conciliar os interesses dos dois grupos, mas deixando claro que considerava os judeus estrangeiros em Alexandria. Na Guerra dos Judeus,
} 
Em relação aos egípcios, a situação era um pouco diferente. A camada sacerdotal beneficiou-se em inúmeros setores e foi muito favorecida pelos dirigentes romanos. Apesar de o demótico (língua egípcia) predominar nesses círculos, muitos membros do núcleo sacerdotal tinham aprendido o grego e, mesmo fora do grupo, era mais comum aos egípcios o aprendizado do grego do que o contrário. E, se comparada a outras culturas, os egípcios eram mais dispersos em Alexandria e não parecem ter desenvolvido nenhuma coesão e unidade forte (como os judeus). ${ }^{19}$ Percebe-se então, que se no período ptolomaico as diferenças étnicas criavam barreiras na vivência diária da população, nesse momento, começaram a repercutir na taxação, o que demarcou ainda mais as diferenças entre as comunidades diversas. ${ }^{20}$

Observa-se que a presença do poder romano em Alexandria foi sentida de forma crescente e as mudanças se tornam ainda mais impactantes quando começam a repercutir no cotidiano da população. Diante da nova conjuntura, inúmeras foram as formas dos habitantes de Alexandria responder ao poder imperial e é nesse cenário de questionamento ao domínio romano que a presente investigação se insere. O objetivo do artigo é analisar brevemente alguns documentos de um conjunto de fragmentos de papiro, denominado Acta Alexandrinorum. ${ }^{21} \mathrm{~A}$ importância dos Acta se justifica por nos fornecer elementos para compreender como a romanização foi recebida, entendida e retratada pelos alexandrinos.

Josefo relata que as desordens tinham se tornado universais no período do embate e os conflitos antigos entre os grupos tinham se acirrado ainda mais em Alexandria. $\mathrm{O}$ autor narra mais um conflito ocorrido no reinado de Nero que teria começado com uma pequena disputa no anfiteatro dos gregos, tendo, contudo, alcançado grandes dimensões. (JOSEFO. Guerra dos Judeus 2. 487-498). ${ }^{19}$ HUZAR, Eleanor G. Alexandria ad Aegyptum in the Julio-Claudian Age. In: HAASE, Wolfgang; TEMPORINI, Hildegard. (eds.) Aufstieg und Niedergang der Römischen Welt II.10.1. Berlin; New York: Walter de Gruyter, 1988, p. 634.

${ }^{20}$ Ellen Birnbaum acredita que, mesmo que já existisse em Alexandria estranhamento e até algum tipo de hostilidade entre os grupos sociais, dificilmente eles tinham resultado em conflitos ou discordâncias maiores. Foram as questões políticas e sociais que tornaram as diferenças mais evidentes e acabaram por resultar em maiores problemas. BIRNBAUM, Ellen. Portrayals of the wise and virtuous in Alexandrian Jewish works: Jews' perceptions of themselves and others. In: HARRIS, William V. e RUFFINI, Giovanni (eds.). Ancient Alexandria between Egypt and Greece. Leiden; Boston: Brill, 2004, p. 160. Sob a mesma perspectiva, Bowman salienta que, apesar dos sinais claros de distinção na religiosidade entre os grupos no período romano, a diversidade não tinha sido a causa real de tensão em circunstâncias normais, apesar de, em alguns momentos, ter sido o meio através do qual as tensões foram expressas. Mesmo que fossem realmente os aspectos culturais e religiosos o que mais distinguia os grupos, no geral, eles souberam conciliar seus costumes e estabelecer diálogos entre suas tradições. BOWMAN, Alan, op. cit., 1986, p. 179.

${ }^{21}$ MUSURILLO, Herbert. Acts of the pagan martyrs. New York: Oxford University Press, 1954. 
Nosso objetivo é ressaltar, em alguns textos desse conjunto, aspectos que ilustrem os modos como os alexandrinos perceberam a chegada do poder imperial na cidade e o cenário de agravamento das disputas entre alexandrinos e judeus. Ou seja, não trataremos aqui de todo o grupo de documentos agrupados pelos Acta, mas selecionamos alguns que consideramos mais ilustrativos para a análise aqui proposta.

Antes de nos determos especificamente na análise dos cinco documentos selecionados, julgamos essencial apresentar algumas considerações sobre o cenário de descoberta e edição dos textos, já que se trata de um gênero ainda relativamente pouco conhecido nos círculos acadêmicos brasileiros. A maioria dos escritos que compõem os Acta foi encontrada no conjunto dos lotes de papiros em Oxyrhynchus, no Egito, entre o final do séc. XIX e o início do XX, quando também começam a ser editados e publicados. Assim, os fragmentos foram sendo publicados separadamente e por diferentes equipes, daí a nossa dificuldade em saber precisamente o contexto e local de descoberta de muitos deles, pois nem todos os editores explicam por completo o percurso de "resgate" dos escritos. ${ }^{22} \mathrm{Na}$ tentativa de reunir os textos e caracterizá-los, observa-se um esforço dos historiadores em encontrar neles algum elemento semelhante que servisse de denominador comum entre os escritos. Sugerem, então, a hipótese de um gênero literário em meio à dispersão, que intitulam de Acta Alexandrinorum. Assim, o agrupamento dos textos, sua definição e nomenclatura, resultando na sua caracterização atual como um conjunto documental, foi obra de seus editores.

Em virtude da falta de acesso à maior parte das primeiras edições sobre os documentos e ao seu contexto de descoberta e publicação, além da escassez de obras que tratem especificamente do tema, dependemos excessivamente da obra de Herbert Musurillo, Acts of the pagan martyrs, sem a qual a presente pesquisa não teria se realizado. Especialmente no que se refere aos dados técnicos referentes ao processo de reconstituição, publicação, edição, local e data de descoberta dos textos. Dessa forma, sua obra o tornou o maior especialista dos papiros, pois reuniu os textos, novos e antigos, e os organizou e publicou de forma mais acessível aos estudiosos modernos. ${ }^{23}$

\footnotetext{
${ }^{22}$ BAGNALL, Roger, op. cit., 1995, p. 27.

${ }^{23} \mathrm{O}$ autor revisou edições anteriores dos textos, que considerou precipitadas em muitos momentos, e propôs uma versão mais colada ao texto grego e com menos interpretações do que poderia estar presente nas lacunas, como fez seu antecessor Von Premerstein, seu alvo maior de críticas. Sua proposta para os textos é mais cuidadosa, no sentido de só traduzir realmente o que faz sentido
} 
As semelhanças entre os vários papiros referem-se à forma, à estrutura e, principalmente, às motivações, já que a maioria descreve episódios de alexandrinos em embate com o poder romano. No entanto, a disparidade entre eles, em relação a pontos centrais, é visível em alguns momentos. Portanto, é arriscado qualquer tipo de generalização que tente definir a natureza e o propósito dos documentos como uma unidade de textos. Ou seja, deve-se ter cautela ao se referir aos Acta como um grande "bloco" ou gênero e ter em mente que o próprio agrupamento das fontes e sua nomenclatura são artificiais, daí as tentativas de definições gerais serem arriscadas.

A análise paleográfica dos textos indicou que foram compostos entre o final do séc. II e início do III. Mesmo que os escritos sobreviventes sejam cópias de originais anteriores, a existência de tais versões posteriores sugere que ao menos a popularização e divulgação foram mais tardias do que sua produção. Outro fator relativo à divulgação, ainda que restrita, dos textos se refere à variedade de locais em que eles foram encontrados no Egito. Todos envolvem Alexandria e seus habitantes, mas nenhum dos fragmentos foi encontrado lá, o que sugere um ímpeto de expandir certas ideias correntes na cidade para além dos seus limites geográficos. Acredita-se que o grupo ao qual se pode atribuir a sua autoria seja a elite grega do Ginásio de Alexandria, já que menções e exaltações a eles estão presentes em quase todos os fragmentos.

O Ginásio era o centro maior da vida cívica e de formação intelectual grega em Alexandria. Bowman e Rathbone sugerem que o vácuo causado pela ausência da Boulé fez essa elite conquistar, além de destaque no cenário cultural e social, também representatividade política, em Alexandria e diante dos romanos. Millar realça que importantes questões cívicas eram decididas no Ginásio e, quando embaixadas e petições eram enviadas ao imperador para resolver questões variadas, comumente eram os cidadãos do Ginásio os escolhidos para se posicionar diante dos romanos, já que não eram apenas homens letrados, mas

como frase. Isso é verdade para os textos já editados e publicados, a partir dos quais ele propõe uma nova tradução, edição e, depois de tudo, interpretação, categorização e crítica dos textos, mencionando também a importância de seus antecessores em todas as etapas anteriores. Mas ele também sugere a edição de textos antes não trabalhados, resultado de novas descobertas da sua época. Alguns mais fragmentários e dúbios ele não traduz, mas os publica, transcreve e inclui algumas notas filológicas, baseado na edição de seus antecessores. Nesse cuidado por vezes excessivo, ele deixou de fora partes que, apesar da impossibilidade da reconstituição mais precisa, ao menos fornecem importantes pistas a respeito do conteúdo. 
também versados em retórica, mais um fator que facilitaria a receptividade por parte do imperador. ${ }^{24}$

A primeira fonte a ser analisada é o PSI 1160 "O papiro da Boulé". Sua proveniência é desconhecida e o texto está localizado no verso de registros de data incerta, mas a análise paleográfica atribuiu a sua escrita à segunda metade do séc. I. O papiro é o único documento aqui trabalhado em que não são mencionados nomes dos personagens envolvidos, nem do orador alexandrino e nem do imperador, o que dificulta um pouco a datação mais precisa. Pela situação descrita e as questões levantadas, é certo que se refere ao início do período imperial. Mas, pelo tipo de argumentação do alexandrino, que parece já denotar um relativo conhecimento a respeito das práticas romanas (pela constante menção a cargos e taxações), acredita-se que o texto diz respeito a algum principado posterior a Augusto, possivelmente Tibério ou Cláudio. Com relação ao conteúdo, relata o pronunciamento de um alexandrino em discurso direto na presença do imperador, enumerando as vantagens que a concessão de uma Boulé traria não apenas a Alexandria, mas ao próprio soberano. O tom de sua fala é respeitoso, mas, no desenvolvimento da argumentação, notam-se alguns trechos de questionamento das práticas imperiais, indicando uma reação à perda da autonomia política de Alexandria que a conquista de uma Boulé visaria resgatar.

É possível vislumbrar no documento a tentativa do personagem alexandrino que está discursando de delimitar bem o grupo que considera representativo dos alexandrinos (dentro e fora da cidade). $\mathrm{O}$ alexandrino expõe a sua preocupação de que muitas pessoas que deveriam se sujeitar ao pagamento de impostos estavam sem alistamento nos arquivos públicos e, consequentemente, diminuindo o valor a ser pago. Dessa forma, ele salienta que uma Boulé evitaria situações como essa e cuidaria também (col. ii, 1. 5 e 6) “(...) para que homens não-educados e não-domesticados não contaminem o puro corpo de cidadãos dos alexandrinos. (...)" ${ }^{25} \mathrm{O}$ trecho indica que estaria havendo menor controle na concessão da cidadania alexandrina. Embora aqui não se mencione nenhum grupo social ou étnico específico e nem se evidenciem os elementos que estariam "poluindo" o corpo de cidadãos, fica expressa a tentativa de restringir a entrada no grupo seleto.

\footnotetext{
${ }^{24}$ BOWMAN, Alan; RATHBONE, Dominic, op. cit, 1992, p. 115. MILLAR, Fergus. The Emperor in the Roman world: 31 B.C. - A.D. 337. London: Duckworth, 1977, p. 8.

25 "(...) kai tò $p\{0\}$ íteuma tv $n \mathbb{A}$ lexandreíwn a lk Jér aion uáracon aq̆reptoi kaì a nágwgoi gegonótes a Eqrwpoi mol únwsi* (...)"
} 
Na sequência, menciona-se a situação contrária, não a ausência de cobranças, mas cobranças injustas, provavelmente de pessoas que deveriam ser isentas e estavam pagando. Esse trecho apresenta várias questões: que a Boulé fiscalizaria, ainda, a renda pessoal do príncipe, já que, controlando melhor a coleta de impostos, o que seria destinado à fortuna do imperador também seria mais bem controlado. Realça, além disso, que a Boulé seria auxiliada e fiscalizada pelo prefeito romano, o que indica que a autonomia de Alexandria seria ainda, de alguma forma, restrita pelo poder romano. $\mathrm{O}$ trecho propõe uma tentativa de conciliação, ou seja, uma inserção nas estratégias romanas, mas com o objetivo de "driblar" seus métodos, mostrando ao príncipe que ele ainda tinha meios de fiscalizar as resoluções dos alexandrinos através de seu prefeito. Tal argumento pode ter sido empregado também como artifício para se fazer ouvir pelo imperador, pois ciente das vantagens que uma Boulé traria a ele mesmo, o soberano poderia mais facilmente negociar os pedidos dos alexandrinos.

Na sequência, o alexandrino continua enumerando as vantagens que a Boulé traria ao próprio príncipe. A alegação segue: (col. ii, 1. 11-14) “(...) E se for necessário enviar uma embaixada a ti, ela mesmo escolheria os adequados, e se certificará que ninguém sem distinção possa partir e que ninguém [preparado] fuja ao serviço da pátria.(...)" ${ }^{26}$ Aqui fica mais nítido que tais membros do corpo de cidadãos, que também poderiam representar a cidade diante do príncipe, deveriam ser homens de distinção, o que na Antiguidade não era apenas um critério econômico, mas principalmente étnico-social. Assim, perante o soberano, os adequados seriam homens com distinção e nativos de Alexandria. Nota-se, entretanto, um forte vínculo entre educação, distinção e pureza cultural e, além disso, pertencimento à Alexandria por origem. Ou seja, indica mais do que uma preocupação política e de natureza social.

$\mathrm{O}$ imperador pronuncia-se apenas no final dizendo que se decidiria a respeito das questões apontadas. Podemos observar em "O papiro da Boulé" o intuito de se circunscrever de maneira sutil qual era o seleto grupo de alexandrinos que estava se manifestando nos textos, mas sem se explicitarem os alvos de crítica, talvez pelo momento não propício e para não criar indisposição com o César. Mesmo que a preocupação maior seja realmente com a presença de

\footnotetext{
26"eøi dé, ei ldéoito presbeían pròs sè pémpein, auth proceirizhtai toùs epithdeíous, kaì [mhte åe]mnóstiselpor eúshtai [[mhte euquetós tic]] mhte e[uquetós tis] wo f eúgni tìn tṇ̂s patrídos uphresían."
} 
pessoas indesejáveis no que deveria ser o restrito corpo de cidadãos alexandrinos, a menção aos oficiais romanos que não estavam se portando de acordo com o exigido pela norma pode ser considerada uma sutil crítica ao Império. Nesse sentido, o autor está sugerindo que a Boulé seria uma mediadora entre o imperador, os oficiais e o povo.

A intenção do texto e o pedido por uma Boulé ambicionariam o resgate de uma autonomia alexandrina no que se refere à sua representação política e "pureza" cultural (aqui relacionada à distinção, ascendência grega e origem alexandrina). A sequência da argumentação deixa claro que não era o Império que estava "roubando" tal autonomia, a causa principal seria a infiltração de pessoas com pouca qualificação no meio político e que estavam ameaçando a preponderância do seleto grupo de alexandrinos (na cidade e diante de César). A posse de uma Boulé permitiria aos alexandrinos algum controle de sua vida cívica e da composição de suas instituições. O texto é também claramente uma reação às novas definições de status impostas, já que, na delimitação dos grupos baseada nos critérios que o poder imperial tinha elaborado, novas categorias sociais começariam a se inserir nos grupos de poder. Nesse sentido, questões antes decididas no domínio da cidade passam a ser determinadas pelos romanos. Dessa forma, em virtude dos conflitos que se manifestariam com mais força num momento um pouco posterior (se o papiro se referir ao reinado de Tibério e não de Cláudio), e pelo conteúdo da resposta da carta de Cláudio, que dialoga em inúmeros momentos com o papiro da Boulé, o mais provável é que a queixa seja aos direitos que os judeus estavam conquistando entre os romanos. ${ }^{27}$ Percebe-se, contudo, que as insatisfações estavam surgindo, mas tentariam ser negociadas.

As relações de "O papiro da Boulé" com a carta são visíveis, mas, como esta pondera também sobre outras questões, o papiro poderia ter sido apenas

\footnotetext{
${ }^{27}$ A referida carta, de 41 d.C., é um pronunciamento do imperador Cláudio a uma série de pedidos dos alexandrinos no primeiro ano de seu reinado, discutindo também questões e problemas que estavam ocorrendo em Alexandria (Carta de Cláudio aos alexandrinos. Select Papyri II, p. 79-89). Por exemplo, no que se refere à cidadania, Cláudio confirma a de todos aqueles que se tornaram efebos até o seu Principado. Entende-se, então, que novas cidadanias não seriam concedidas a partir daquele momento, algo que favoreceria ao menos uma das queixas de "O papiro da Boulé". Cláudio aprova todos os direitos concedidos à cidade pelos príncipes, reis e prefeitos anteriores, como Augusto já tinha feito. Mas, respondendo ao pedido por uma Boulé, Cláudio contesta dizendo que com relação aos reis anteriores ele não sabe quais foram as suas práticas com relação à existência da Boulé, mas que, sob os Augustos anteriores, ele está ciente de que não tiveram e argumenta que, como se trata de um projeto novo, cujas vantagens ainda não lhe estão claras, ele ainda se decidiria se o projeto seria viável e, caso fosse, o melhor modo de ser executado.
} 
um dos motivadores de Cláudio na sua escrita e ter sido enviado muitos anos antes. Ao que parece, o papiro foi uma petição enviada ao príncipe e a carta seria, então, a negação ao pedido da Boulé. Nesse sentido, o papiro pode ter sido apenas uma e não necessariamente a única petição pela Boulé. Mesmo enviado em principados anteriores, no de Tibério ou Calígula, "O papiro da Boulé" deve ter sido um dos elementos considerados por Cláudio ao elaborar sua carta, pois o diálogo entre os textos é visível em inúmeros momentos. Ou seja, as insatisfações do grupo alexandrino estariam de alguma forma alcançando as esferas máximas do poder imperial e, nesse sentido, a ideia de protesto do grupo já se manifesta nesse texto.

O P. Oxy. 1089: "A entrevista com Flaco" foi encontrado em Oxyrrhynchus (atual Behnesa). O texto foi escrito no verso de um registro de terra do séc. II d.C. e sua produção atribuída à primeira metade do séc. III d.C. Pelo documento ser tão fragmentário e por não ser possível a leitura do começo e final, a situação é nebulosa e pouco pode ser esclarecido a respeito do episódio ou do seu objetivo de escrita. A datação do cenário narrado é possível pela presença de personagens que podemos localizar em outras fontes, nos Acta Isidori e no In Flaccum e Legatione ad Gaium de Fílon.

O documento descreve um arranjo secreto entre Flaco, prefeito romano do Egito, e dois alexandrinos do Ginásio, Isidoro e Dionísio. O local da negociação era o Serapeum, templo à divindade Serápis e fica explícito no texto a importância do espaço físico do templo como local eleito. Apesar de não ser possível saber o teor do debate, fica evidente que a situação entre o prefeito e os alexandrinos era tensa. Nesse documento, o representante imperial é o prefeito de Alexandria, o imperador não está presente como em outros.

A divindade Serápis é, por muitos comentadores, considerada como um elemento chave para analisar a política que os reis ptolomaicos dedicaram às culturas grega e egípcia e o tipo de vínculo e limites que pretendiam estabelecer entre elas. Foi nesse contexto que Ptolomeu I Sóter instituiu o culto a Serápis, divindade resultante da fusão de elementos gregos e egípcios, que se tornou o deus tutelar de Alexandria e atingiu grande popularidade, principalmente no período romano, sob Trajano e Adriano. ${ }^{28}$ Sabe-se da instituição do culto pelo

\footnotetext{
${ }^{28}$ Grafton Milne acredita que a instituição do culto a Serápis no Egito teria a finalidade de sintetizar os elementos das religiosidades grega e egípcia, talvez para criar algum vínculo de entendimento entre as culturas, promovendo uma espécie de sincretismo entre as duas religiões. Mas realça que, apesar da criação do culto ter tido aparentemente esse fim de "conciliação", os egípcios resisti-
} 
primeiro Ptolomeu. Fraser ressalta, porém, que há indícios de que a divindade teve uma origem bem anterior e o papel crucial do rei foi o de popularizar e tornar a sua adoração oficial. Aparentemente, o culto era originário de Mênfis e derivado do de Osíris-Ápis. ${ }^{29}$

Acreditamos que, mesmo que o ideal da crença fosse a conciliação entre as tradições grega e egípcia, o estabelecimento e a popularização da adoração a Serápis ficam mais evidentes como um símbolo de algo especificamente alexandrino, da nova identidade que ali se formara. Atualmente, alguns historiadores têm destacado tal ideia, ou seja, a de que os Ptolomeus instituíram o culto com o fim maior de servir de ícone da dinastia e da nova cidade. Assim, a criação da divindade ia muito além de uma mera tentativa de sincretismo. Dever-se-ia, desde cedo, realçar a fundação de algo alexandrino, mas, para isso, seria necessário considerar a religiosidade e a cultura dos "elementos fundadores" da nova cidade. ${ }^{30}$

Antes de tratar propriamente da documentação, convém mencionar rapidamente a narrativa de Fílon, já que seu In Flaccum se dedica exclusivamente à caracterização dos mesmos personagens tratados na "Entrevista com Flaco". Os alexandrinos Isidoro e Dionísio são descritos como os principais articuladores da política antijudaica que começou a se manifestar em Alexandria e resultou no "massacre" de 38. Flaco foi prefeito romano no Egito entre 32 e 38 d.C. e, segundo Fílon, fez uma boa administração nos cinco primeiros anos de seu cargo,

ram a aceitá-la e, num primeiro momento, o culto parece ter sido realmente dirigido aos gregos. MILNE, Grafton, op. cit., 1924, p. 202. Lewis salienta que, embora o sincretismo tenha sido o objetivo maior na criação de Serápis, cada grupo o cultuava separadamente, segundo suas tradições. LEWIS, Naphtali, op. cit., p. 70. Como Fraser, El-Abbadi e Takacs acreditam que o culto a Serápis seria então uma tentativa de uniformizar a variedade de crenças que lá se encontravam, um "aglutinador" comum para a diversidade. EL-ABBADI, Mostafa, op. cit., 1993, p. 46.; TAKACS, Sarolta. Alexandria in Rome. Harvard Studies in Classical Philology, 97, 1995, p. 265.

${ }^{29}$ FRASER, Peter M., op. cit., 1972, p. 246 e 250.

${ }^{30}$ Lilly Kahil ressalta que Ptolomeu I Sóter pensou no culto como uma forma de "unificar" étnica, social e culturalmente os novos (greco-macedônios) e antigos líderes (dinastia faraônica) do Egito. A autora destaca, contudo, que se deve entender o estabelecimento da adoração a Serápis principalmente como uma divindade própria de Alexandria, patrona da nova dinastia, e que representava seu poder (a corte real e a população grega). Ou seja, não se trataria de uma tentativa de promover a integração religiosa, pois a intenção de manter os gregos em posição privilegiada era nítida. KAHIL, Lilly. Cults in Hellenistic Alexandria. In: GREENBERG, Mark; HAMMA, Kenneth; GILMAN, Benedicte; MOORE, Nancy (eds.). Alexandria and alexandrinism: Papers delivered at a symposium organized by the J. Paul Getty Museum and The Getty Center for the History of Art and Humanities and held at the Museum, April 22-25, 1993. Malibu, California: The J. Paul Getty Museum, 1996, p. 77-78; DUNAND, François. The factory of gods. In: JACOB, Christian; POLIGNAC, François de, op. cit., 2000, p. 160. 
sob o Principado de Tibério, com quem tinha uma grande proximidade. Uma de suas primeiras atitudes como prefeito foi fechar os "clubes e associações" de Alexandria (Fílon. In Flaccum, 4). Tais atitudes logo o indispuseram com os membros do Ginásio, também descritos por Fílon como os líderes da "facção nacionalista". Por estar numa situação complicada com Calígula e percebendo a deterioração de seu poder, Flaco oferece auxílio a esse mesmo grupo e gradualmente se envolve no "movimento antijudaico" que estavam iniciando (In Flaccum, 19-24). Fílon relata que, ao aliar-se ao grupo, Flaco tornou-se um verdadeiro "fantoche" para a execução dos planos dos alexandrinos (In Flaccum, 19).

O que fica mais marcado no texto é o peso concedido à divindade Serápis na condução das negociações, como se percebe na nota narrativa no início da col. ii:

(col. ii, 1. 24-33) Flaco então [subiu] ao Serapeum ordenando que o negócio fosse preparado secretamente. Sobe também Isidoro com Afrodisia e Dionísio, e tendo entrado no interior do templo, Isidoro e Dionísio cultuaram o deus. E então o homem velho se atirou para baixo e de joelhos se segurando a Dionísio disse: $[\ldots]^{31}$

Destaca-se a importância da divindade para o trato realizado, talvez para conceder legitimidade ao processo. Tendo sido algo pensado ou não, ficam evidenciados a importância e o respeito despertados pela divindade, não apenas para os alexandrinos, mas também para o prefeito romano. O objetivo do autor do relato poderia ser o de demonstrar a força da cultura alexandrina até entre os romanos, já que Flaco também se curvaria à divindade. $\mathrm{O}$ ambiente carregado fica visível no seguinte trecho (provavelmente pronunciado por alguém que estaria tentando apaziguar a situação):

(col. ii, 1.33- 42) Veja! Senhor Dionísio, o velho homem diante de Serapis: "Não cometa violência contra Flaco, mas [senta-te em conselho] com os velhos. Ou tendo sido tu levado (...)? Mude de ideia jovem Dionísio!”

E ele respondeu: "Combinas bem, mas não queres que eu rejeite Flaco novamente? Se é necessário estar com ele na [lua] nova [vou livremente]”. ${ }^{32}$

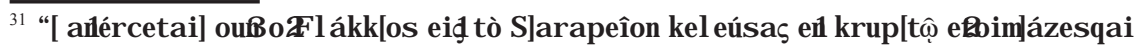

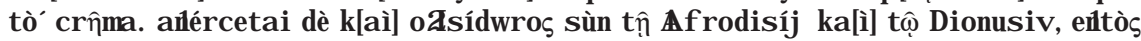
dè toû new>e[i ls el qóntes \{de\} 02Lsídwros kai o2Dionúsiosprosekúnhsan. ka ì tóte ebipy en ezution [02g]eraiós, gonukl inǹs dlled[ó]men[0]s [t] ô̂ D[i ]onusíou I égwn, (...)" 32 "(...) i doú, d[é]s p [ot]a Di onus ie, a atikrù toû $S$ a [rá ]p io[s] ozger a iós* mì biázou pròs

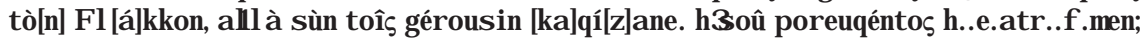


Ao que parece, a tal negociação já deveria ter ocorrido anteriormente, mas por receio de uma das partes (provavelmente Flaco) ainda não tinha sido realizada. Depois desse trecho, a fonte fica quase ilegível, Flaco menciona apenas que o arranjo estava pronto e, em seguida, há uma fala, provavelmente do tal oficial/ mediador, suplicando para Flaco não fazer mal a Isidoro e Dionísio. Não há meios de saber o teor do acordo, mas fica evidente se tratar de algo secreto, por estar ocorrendo no templo. Além disso, vemos que Flaco receberia pela transação que, sendo secreta, poderia também ser algo ilegal para um prefeito. Nesse sentido, além do ambiente conflituoso entre o oficial romano e os alexandrinos, Musurillo sugere ser a intenção do autor ilustrar a corruptibilidade do oficial romano. ${ }^{33}$ Como os envolvidos eram personagens já conhecidos entre os alexandrinos, poderia ser também o ideal da narrativa propor um enaltecimento da memória de Isidoro e Dionísio e servir de contraponto e defesa ao relato de Fílon, através da crítica à Flaco. Ou seja, os alexandrinos do Ginásio pretendiam exaltar seus líderes e, paralelamente, reforçar a oposição ao representante romano na cidade.

Antes da condenação de Isidoro (narrada nos Acta Isidori) e depois do conflito com os judeus em 38, mas ainda no reinado de Calígula (em 39 ou 40), Isidoro esteve presente em outra embaixada ao imperador contra os judeus de Alexandria. Quando Cláudio sobe ao poder, ele tenta estabelecer uma liderança mais pacífica que seu antecessor. Como vimos, sua carta seria um pedido por conciliação entre os grupos, o que não parece ter se cumprido, pois a fala de Isidoro nos Acta Isidori continua expressando a oposição ao judaísmo.

Os Acta Isidori são ambientados no reinado de Cláudio e foram encontrados em três versões diferentes. Relatam o julgamento de Isidoro, cidadão alexandrino, e seu pronunciamento contra o rei judeu Agripa (provavelmente o I) diante do imperador. Sabemos que se trata de uma mesma coleção de textos por referiremse ao mesmo episódio. No entanto, a recensão $\mathrm{C}$ é relativamente diferente de A e B em alguns aspectos que são mais semelhantes em relação ao conteúdo.

A recensão A (Chrest. 14) está localizada no verso de um registro do tempo dos Antoninos, e sua escrita foi datada entre o final do séc. II e o início do III. A proveniência dos dois fragmentos é desconhecida. Trata-se da versão mais completa das três. A proveniência da recensão B (P. Lond. Inv. 2.785) também

meta nóhs on, ték[non] D [i ]onús ie. o 2dè a ât eîp en* euq̣etîs, [a ll à eđm]è deút e[r ]on mì B oúl ei

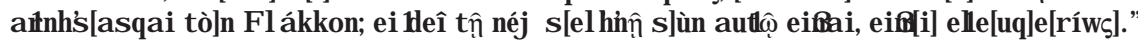
${ }^{33}$ MUSURILLO, Herbert, op. cit., 1954, p. 95. 
é desconhecida e o texto encontra-se no verso de um documento do séc. II. Sua escrita foi atribuída pelo editor ao início do séc. III. Por algumas linhas, as versões A e B são equivalentes, com sutis mudanças no vocabulário e menor detalhamento na continuidade da nota introdutória da B. No entanto, as semelhanças são suficientes para indicar que se referem ao mesmo episódio. A recensão $\mathrm{C}$ (P. Berol. Inv. 8.877) foi provavelmente escrita entre o final do séc. II e início do III, no verso de um registro pouco anterior, e sua proveniência também é desconhecida. As três versões narram embates de Cláudio com Isidoro em seu julgamento e estavam presentes também outros enviados alexandrinos. Isidoro estava sendo acusado de algo cometido contra o rei judeu Agripa. Aparentemente, já estava condenado, mas antes da execução queria fazer alguns apelos a Cláudio, denunciando os problemas que estavam ocorrendo em Alexandria. Nota-se uma indisposição do alexandrino em relação ao rei e ao judaísmo de modo geral, e, no decorrer da argumentação, fica nítido o tom de desafio ao imperador. Analisadas em conjunto, as três versões dos Acta Isidori marcam um posicionamento mais incisivo em relação a certas ideias, se comparadas aos textos mencionados até agora.

Nas versões A e B chama a atenção o detalhamento da nota introdutória por destacar a presença de muitos envolvidos no julgamento de Isidoro. Apesar do menor detalhamento da nota na recensão $\mathrm{B}$, a grande quantidade de pessoas presentes também é citada. Ao realçar a presença de muitos, podia ser a intenção do autor enfatizar a importância do julgamento de um alexandrino ginasiarca também entre os romanos, ou seja, teria o intuito de marcar a sua proeminência.

$\mathrm{Na}$ sua primeira fala, nas versões A e B, Isidoro "implora" que o imperador ouça seu (col. ii - 1.10 e 11) "relato a respeito dos sofrimentos da sua cidade". ${ }^{34}$ Observa-se aqui um tom dramático e que poderia ter o propósito de despertar, em quem lesse ou ouvisse, um sentimento de piedade em relação à situação de Alexandria. Cláudio atende ao pedido de Isidoro e segue uma nota narrativa (nas versões A e B) em que fica claro que o alexandrino já estava numa situação complicada diante do príncipe: (cont. col. ii - 1.14 e 15) "Todos os [senadores] chamados concordaram com isso, sabendo o tipo de [homem que Isidoro] era". ${ }^{35}$

Evidencia-se acima a situação polêmica do alexandrino e como sua figura era familiar nos círculos imperiais (como vimos no relato de Fílon), um homem

\footnotetext{
34 "kúrié mou Kaîsar, tôn goná[twn sou déoma i] a loûs a í mou tà ponoûn[ta tḥ̂patrídi.]"

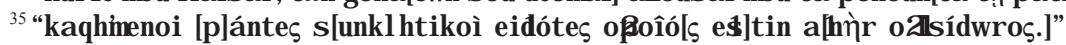


insistente e propenso a confusões e que, por isso, consegue ser ouvido. O relato continua no dia da audiência e inicia com o aviso de Cláudio para não dizer nada contra Agripa, pois Isidoro já tinha matado outros amigos seus. Ou seja, o imperador estava insatisfeito com o alexandrino por episódios anteriores e este estava em julgamento por ter insistido nas mesmas atitudes já censuradas em outros momentos. Depois dessa parte, as duas recensões mudam de rumo. $\mathrm{Na}$ A, Isidoro responde: (col. iii, L. 5-7) "Isidoro: Eu ouvi as ordens do rei da época. Também tu digas quem desejares que denunciarei". ${ }^{36}$ Isidoro assume a culpa, mas não mostra arrependimento ou justificativa de qualquer tipo, e nem se curva e se intimida diante do príncipe. Na sequência do escrito, após sucessivos embates entre Isidoro e Cláudio, o soberano faz a seguinte pergunta: (cont. col. iii, L. 7- 12) “Cláudio César: Isidoro, você é mesmo filho de atriz? Isidoro: Eu não sou nem escravo, nem filho de atriz, mas ginasiarca da gloriosa cidade de Alexandria. Mas você é o filho rejeitado da judia Salomé!"37

O trecho demonstra certa ironia na fala do imperador, já que chamar Isidoro de "filho de atriz" seria chamá-lo de mentiroso. Esse pedaço é tipicamente retórico, pois Isidoro se aproveita da própria argumentação de Cláudio para invertê-la e acusá-lo (desmerecendo sua ascendência) e assim, expor a posição de prestígio do alexandrino. A acusação ao imperador de ser "filho rejeitado da judia Salomé" talvez servisse para desprezar a ascendência do imperador em contraste com a pretensa origem ilustre de Isidoro. Ainda nesse trecho, procura-se demonstrar a nobreza de sua posição, diretamente associada à exaltação de Alexandria. Fica claro que a situação na cidade não era pacífica, pelo tom dramático do início do depoimento de Isidoro. Como a fala era dirigida contra Agripa, pressupõe-se que Isidoro entende que "os sofrimentos da cidade" estavam associados a algo ocasionado pelos judeus.

$\mathrm{Na}$ versão B, quando se cita Agripa, o imperador responde a Isidoro num tom declarado de indisposição ao alexandrino e o acusa de perseguir o rei judeu. Isidoro responde então, da seguinte forma: (col. i, 1. 17- 21) "Isidoro: Meu senhor César, que [te importa] um judeu de três dracmas como Agripa? Cláudio

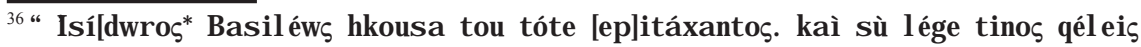
[ka]thgorhs ' $w$ '."

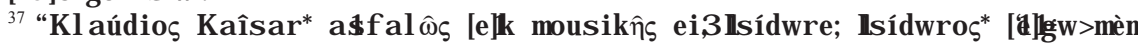
ouk ei mi doûlos oudè mousikn̂s [ui Rós, all à diashmou pól ews [ $\mathbb{A}$ ] I exan[dr]

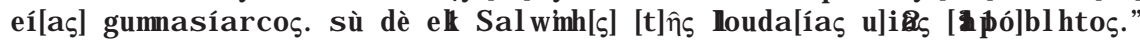


César: O que [afirmas]? Você é o [mais insolente] de todos os homens!" 38 A expressão usada para se referir a Agripa manifesta a intenção do alexandrino de classificá-lo como um judeu de pouco valor, sem escrúpulos, que, portanto, não merecia a defesa do imperador. Pretendia destacar com isso que a atenção do príncipe deveria se voltar para os anseios do grupo alexandrino.

Nessa versão estão ilustradas (em comparação com a A) as razões para o julgamento de Isidoro, acusado de algo que teria cometido contra o rei Agripa. $\mathrm{O}$ alexandrino se defende ressaltando os problemas em Alexandria. Como as acusações do imperador se dirigem contra Isidoro, não há explicação sobre quais eram os motivos de queixa do alexandrino. Já na versão A nada mais se menciona a respeito de Agripa e a crítica ao judaísmo fica explícita na desprezível alusão a Salomé. No entanto, a preocupação principal parece ser o desafio a Cláudio. A recensão A termina com a fala ofensiva de Lampo (alexandrino companheiro de Isidoro e também polêmico, segundo as palavras de Fílon, mas não se sabe o seu papel nesse texto). Lampo tinha se manifestado anteriormente dizendo que estava prevendo a morte e agora reforça: (cont. col. iii, L. 13- 17) "Lampo disse a Isidoro: Mas nós podemos também nos entregar a um rei transtornado? Cláudio César: Aqueles que eu chamei para condenar à morte Isidoro e Lampo". 39

O trecho indica a decisão já tomada pelo imperador de condenar os alexandrinos, pois Lampo pede a Isidoro para não argumentar mais e, além disso, chama Cláudio de louco, ou seja, perde completamente o respeito pelo soberano. Essa parte salienta que, mesmo prevendo a condenação, os alexandrinos não iriam se calar diante da autoridade e marcariam suas ideias. Na sua última fala, Cláudio parece se dirigir ao executor e não mais aos alexandrinos, pois a decisão de matá-los já estava tomada e o último desrespeito de Lampo teria sido a "gota d'água" para que a execução fosse logo realizada. Na recensão B, depois de Cláudio acusar Isidoro de perseguir Agripa, o alexandrino insulta o rei judeu, como já vimos acima, e Cláudio rebate. Percebe-se, então, que, nesse texto (recensão B), o objeto de crítica é mesmo o judeu, apesar da fala contra ele ser também dirigida ao príncipe.

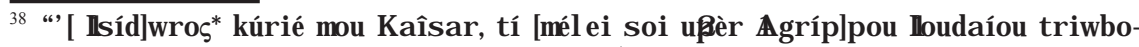

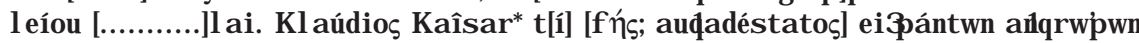
[c. \&e ]keính ei ithkénai."

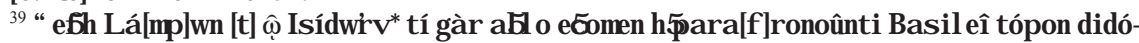

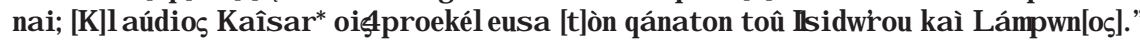


Apesar do estado lacunar da col. ii (recensão B), observa-se a continuidade entre o diálogo de Isidoro e Cláudio. Podemos perceber, nas duas primeiras versões, a complicada situação de Isidoro, mas ele não se intimida e se aproveita da certeza de sua condenação para expor suas ideias, num visível tom de desafio. Na versão $C$, os personagens e a situação são as mesmas, mas o texto denota outras preocupações além da descrição do julgamento de Isidoro. A col. i (recensão C) é completamente lacunar e parece ser uma nota introdutória e não um diálogo. A partir do conteúdo sobrevivente, pode-se observar que essa parte não se assemelha ao detalhamento do início do texto nas versões anteriores (que destaca a importância e destaque do julgamento de Isidoro). A col. ii já se inicia com uma resposta de Isidoro à fala de Agripa e do tal Balbilo. Essa parte ilumina pontos que nos são centrais, por isso vale a pena citá-la integralmente:

(col. ii, 1.19-30) Isidoro: "Meu senhor Augusto, considerando seus interesses, [Balbilo] argumenta bem. Mas a ti Agripa, eu desejo replicar sobre o que introduzes [a respeito dos judeus]. Eu os acuso de [desejar atormentar] o mundo inteiro. É necessário [considerar] a comunidade de maneira geral. Ela não é do mesmo temperamento dos alexandrinos, mas vive mais ao modo dos egípcios. Eles não são iguais àqueles que pagam os impostos?" Agripa: "Os pagamentos foram estabelecidos aos egípcios pelos seus dirigentes. Mas ninguém (cobrou) deles". 40

É nítido o desprezo pelos egípcios não apenas na fala do alexandrino, mas também nas palavras do judeu Agripa. Nos Acta Isidori, nada se comenta a respeito das práticas religiosas judaicas, a preocupação em marcar as disparidades entre os grupos se manifesta quando surge a questão referente ao pagamento de impostos. A narrativa é breve com relação a esse ponto, afirma-se apenas que o modo de os judeus viverem (semelhante aos egípcios) deveria resultar no pagamento de impostos, dos quais os alexandrinos seriam liberados. Ou seja, a comparação com os egípcios serviria para deixar os judeus na mesma situação daqueles no que concerne à taxação.

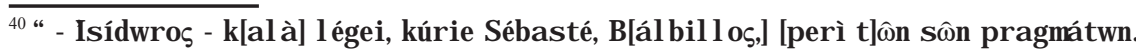

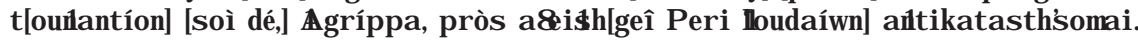
enk[al $\hat{\omega}$ a utoîs] [oti k]ai o $7 \mathrm{hn}$ tìn oilkouménhn [qél ousi] [tarás]sein. deî dè tò kat

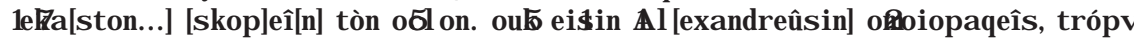

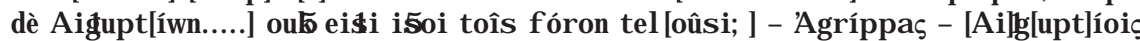

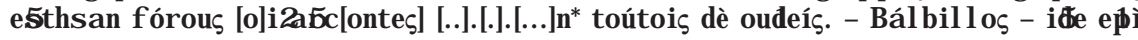
p [hl í]khn tól mhn hrqe[òs a utloû h ho"
} 
Agripa responde que os egípcios foram cobrados pelos seus dirigentes anteriores, provavelmente se referindo aos Ptolomeus. A fala sugere então que, antes dos romanos, os judeus eram isentos ou pagavam menos e, nesse momento, deveriam começar a pagar, algo considerado como motivo de insatisfação em relação aos vizinhos que tinham a cidadania alexandrina (os únicos completamente isentos). Alguns autores sugerem que Agripa foi incluído no relato apenas para realçar a importância do caso e conceder-lhe legitimidade. ${ }^{41}$ De qualquer maneira, a presença ou não do rei não compromete a intenção do relato de propagar uma imagem negativa a seu respeito e da comunidade judaica. É perceptível nos dois relatos a definição de Isidoro como um homem de destaque e polêmico na cidade e que rapidamente se posicionava contra autoridades ou problemas em Alexandria. Sua presença em vários documentos dos Acta também denota seu papel central na condução das negociações e embaixadas ao Império. Consequentemente, talvez os documentos tenham sido escritos para servir de contraponto ao relato de Fílon e explicitar a versão dos alexandrinos a respeito de Isidoro, para promover a sua defesa e preservar a sua memória.

Nota-se aqui uma preocupação semelhante à de "O papiro da Boulé", mas diferentemente deste, aqui não se pretende um silenciamento a respeito dos alvos de crítica. Da mesma forma que no anterior, observa-se o intuito de "isolar" o grupo alexandrino em relação aos outros grupos sociais da cidade, mas isolá-lo principalmente por questões políticas e de status, para que fossem os únicos a ter preponderância diante dos romanos. Como "O papiro da Boulé" tratar-se-ia de uma petição, o tom é mais ameno e, provavelmente por isso, mais cuidadoso em não deixar claro o objeto de contestação. Nos Acta Isidori, como o alexandrino já estava condenado, o objetivo do relato era explicitar os motivos de insatisfação de Isidoro. Observa-se, também, que no papiro a petição foi realizada por cidadãos alexandrinos, mas não se sabe se membros do Ginásio ou não (a cidadania era pré-requisito para a entrada no Ginásio, mas a associação na instituição era apenas uma das formas de obtenção da cidadania e não a única). Em outras palavras, a seleção para o Ginásio era ainda mais restrita que a concessão da cidadania. Nesse sentido, nos Acta Isidori observase o início de uma maior delimitação do grupo de distinção que representaria a cidade, mais restrito aos membros do Ginásio.

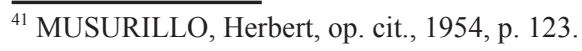


O P.Oxy. 1.242: Acta Hermaisci foi escrito no verso de cópias de contratos da época dos Antoninos. Sua escrita deve, portanto, ser atribuída ao final do séc. II e início do III. Os Acta Hermaisci narram uma embaixada de alexandrinos e judeus diante de Trajano (citado nominalmente). A datação exata do texto é polêmica. Sabe-se, entretanto, que se refere ao reinado de Trajano antes da grande revolta dos judeus (entre 115 e 117). ${ }^{42}$ No começo do texto já fica claro que a situação entre os grupos era espinhosa em Alexandria, mas ao começar o diálogo com o imperador não mais parece se tratar de uma embaixada entre alexandrinos e judeus (os judeus não se pronunciam), e sim do julgamento de Hermaisco, aparentemente já condenado, mas que, ainda assim, dialoga com o imperador num tom de desafio. A narrativa destaca o desprezo ao judaísmo, apesar da fala de Hermaisco ser também nitidamente abusiva ao imperador.

Na nota introdutória, afirma-se que os judeus formaram sua embaixada após terem conhecimento que os alexandrinos estavam enviando a sua. Como nos Acta Isidori, há aqui um grande detalhamento e são citados todos os membros das duas embaixadas. Chama a atenção nessa parte o seguinte trecho: (col. i, 1. 16-18) "Eles então, partiram da cidade, cada um levando consigo seus próprios deuses, os alexandrinos (um busto de Serápis, os judeus)" ${ }^{43}$ Como na continuidade do texto se realça a importância da presença de Serápis, Musurillo completou a lacuna indicando ser essa a divindade levada para representar os alexandrinos. O trecho sugere uma complicada questão: se o judaísmo era tão conhecido nesse meio por suas práticas distintas, como o autor do texto seria ignorante justamente a respeito de algo tão central para a fé judaica? Refere-se ao fato de os judeus não aceitarem o culto a imagens? Ou teria mencionado tal

\footnotetext{
${ }^{42} \mathrm{O}$ conflito iniciou-se em Cirene como uma revolta dos judeus contra os romanos e seus vizinhos helenizados, mas atingiu o Egito e tomou grandes proporções em Alexandria, até que a comunidade judaica foi praticamente dizimada da cidade. A revolta é narrada por Dion Cássio (DION CÁSSIO. História romana 68. 32) e Eusébio (EUSÉBIO. História eclesiástica 4. 2). Eusébio realça que, nesse período, os sofrimentos dos judeus chegaram ao seu clímax, destruindo uma grande multidão deles. Em Alexandria e no resto do Egito e especialmente em Cirene, eles foram tomados por "um terrível espírito de rebelião" contra seus vizinhos gregos. A rebelião se expandiu no ano seguinte tomando a forma de uma grande guerra, quando Lupus era o governante do Egito. Ela iniciou-se em Cirene, sob a liderança de um tal Lucuas e atingiu uma enorme proporção, tomando Alexandria e todo resto de Egito, chegando inclusive a alcançar a Mesopotâmia. Dion Cássio afirma que o tal líder que os judeus teriam escolhido como rei para liderar a revolta se chamava Andreias (e não Lucuas) e realça que os judeus estavam destruindo tanto romanos quanto gregos. $\mathrm{O}$ autor descreve ainda mais detalhadamente as violências cometidas e salienta que, no final, o número de mortos chegou a quase 220 mil pessoas.

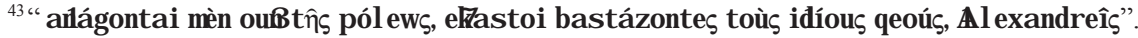


questão justamente para marcar o diferenciamento do judaísmo em relação às crenças pagãs e estabelecer a identidade entre romanos e alexandrinos? Faria isso para tentar demarcar a diferença dos judeus e deixá-los em desvantagem diante dos romanos, enfatizando a estranheza de suas tradições? Ou ainda, como Roberts sugeriu, os judeus estariam carregando a Torá e o autor ou narrador do texto teria feito uma pequena "confusão" ao se referir ao livro sagrado dos judeus como uma divindade? ${ }^{44}$ As possibilidades acima devem ser consideradas. No entanto, muito peso foi dado a tal questão, com base no que estaria presente numa lacuna e não pode ser confirmado. A menção aos grupos carregando seus deuses consigo pode simplesmente significar que cada grupo estava se encaminhando a Roma confiando na própria fé e não necessariamente se referindo a representações físicas de seus deuses.

A narrativa segue realçando que Trajano receberia os alexandrinos em desvantagem. Relata-se que todos os presentes estavam inclinados a favor dos judeus antes mesmo dos embates se iniciarem. $\mathrm{O}$ imperador recebe a embaixada alexandrina com a seguinte fala: (col. ii, 1. 35-37) "Vocês me cortejam como se merecessem um cumprimento no mesmo nível, (depois) do sofrimento tal a que vocês submeteram os judeus!" $45 \mathrm{O}$ favorecimento declarado aos judeus é suspeito, ainda mais num contexto supostamente acalorado entre os grupos. $\mathrm{O}$ autor poderia, com tal afirmação, querer expressar a situação de desvantagem dos alexandrinos diante de um imperador obviamente partidário dos judeus.

Depois das primeiras palavras de Trajano, há uma grande lacuna e, na sequência, novamente uma fala do imperador que inicia remetendo a algo que o alexandrino teria dito antes:

(col. iii, 1. 40-50) [Trajano:] "Você deve estar ansioso para morrer, e desprezas a morte de tal forma, respondendo com insolência".

Hermaisco disse: "Porque, nos perturba ver que o seu Conselho Privado foi invadido por judeus ímpios".

César disse: "Esta é a segunda vez que lhe aviso, Hermaisco: tu estás me respondendo de maneira insolente, tirando proveito do seu nascimento".

Hermaisco disse: "O que você quer dizer, que eu te respondo de maneira insolente, maior dos imperadores? Explique-me isso".

\footnotetext{
${ }^{44}$ MUSURILLO, Herbert, op. cit., 1954, p. 175.

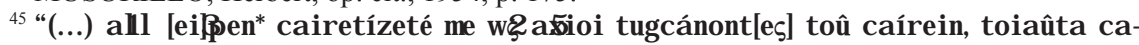
I epà tol mhs ante[s] Loudaíois;",
} 
César disse: "Sugerindo que meu Conselho está repleto de judeus".

Hermaisco: "Então a palavra 'judeu' é difícil de suportar para você? Nesse caso é melhor você ajudar seu próprio povo e não exercer o papel de advogado de judeus ímpios". 46

Nesta parte fica nítido o jogo retórico que Hermaisco pretende, pois inverte a situação para demonstrar, no próprio Trajano, uma posição preconceituosa em relação ao judaísmo. Ou seja, basta uma pergunta de Hermaisco para evidenciar no príncipe toda a ideia que o alexandrino deseja enfatizar, não sendo necessário recorrer a explicações complexas. Ou ainda, a sua indignação se expressa pela sua pretensão de se manter imparcial e não favorecer nenhum grupo. Assim, quando Hermaisco o acusa de favorecer o judaísmo, o soberano se mostra irritado. Nota-se, nessa parte, a indignação quanto aos judeus, mas as soluções para os problemas são cobradas do próprio imperador e o tom com que Hermaisco se refere a Trajano demonstra o intuito de desafiá-lo.

Pode-se notar também, no trecho, uma tentativa de identificação cultural entre alexandrinos e romanos ao se salientar a distinção do judaísmo em relação à identidade dos outros dois grupos. Os alexandrinos estariam se queixando do espaço que os judeus estavam conquistando entre os romanos, o que novamente parece um ressentimento referente às novas definições de status adotadas que acabaram abrindo o "leque" da cidadania alexandrina e das possibilidades de aproximação do imperador (mesma motivação do "O papiro da Boulé" e da recensão C dos Acta Isidori). Após as últimas palavras de Hermaisco, o diálogo é interrompido por uma nota narrativa dizendo que nesse momento o busto de Serápis (que os alexandrinos teriam trazido) caiu repentinamente e se quebrou. O ocorrido deixou Trajano estarrecido, além da multidão que, assustada com o fato, começou a correr para longe do local. A impressão é de esta ter sido a forma encontrada pelo autor para favorecer os alexandrinos, pois o imperador estava mesmo em situação de desvantagem na condução da discussão. Assim, a divindade, de alguma forma "encerrou o assunto", confirmando ainda mais o rumo que a argumentação de Hermaisco estava tomando.

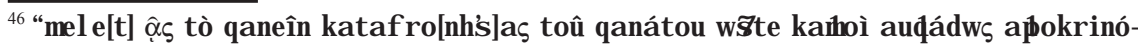

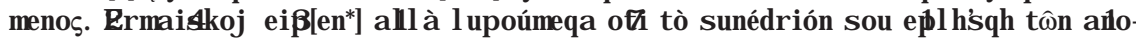

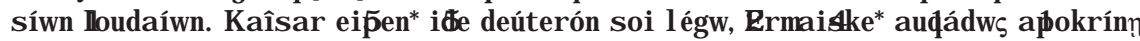

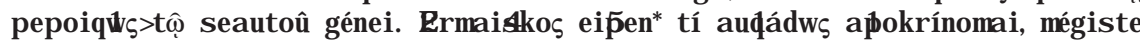
autlokrátwr; dídaxón me. Kaîsar ei pen* oti tò sunédrión mou loudaíwn epoíhsas. Ermai\&kos* ouroun calepón ęti tò oboma tôn loudaíwn; otleíl ei coula páli toîs seautoû bohqeîn kaì mì toîs a dosíois loudaíois sunhgor eîn."
} 
Como na "Entrevista com Flaco", a divindade Serápis recebe um papel central nesse texto, concedendo legitimidade, proteção e razão ao lado alexandrino. Ou seja, seu culto pode ser considerado um elemento essencial na estruturação da identidade alexandrina e na memória que se procuraria perpetuar a respeito de seus cidadãos por excelência, que melhor representariam os anseios da cidade, os membros do Ginásio.

Vimos que os Acta Isidori e os Acta Hermaisci se assemelham em alguns aspectos. Isso é visível no trato dos imperadores, respectivamente Cláudio e Trajano, e na forma com que se dirigem aos alexandrinos, e também no modo dos acusados se dirigirem a eles. A forma de se colocar para o príncipe é cordial e respeitosa num primeiro momento, mas o tom de desafio fica nítido no decorrer dos textos, depois que os imperadores se mostram partidários dos judeus e deixam claro que os alexandrinos (Isidoro e Lampo, e depois Hermaisco) estavam em situação complicada e com a condenação praticamente certa. $\mathrm{O}$ cenário dos Acta Hermaisci é visivelmente de maior gravidade, pelo tamanho das embaixadas dos dois partidos que Trajano recebe. Mas, como nos Acta Isidori, a partir do momento que o embate se inicia, não parece mais se tratar de uma embaixada, já que os judeus não têm voz e os imperadores se pronunciam de forma mais breve que os alexandrinos.

Observa-se que o objetivo nos dois textos é retratar os imperadores como partidário dos judeus e pouco dispostos a ouvir sobre os problemas de Alexandria de que os judeus eram causadores. A indignação diante da comunidade judaica é evidente, mas se cobra do imperador soluções para os problemas e é a ele que os diálogos se dirigem. Ou seja, realça-se o seu papel como juiz de todos os "mundos" que conviviam em Alexandria, contudo, destaca-se também a sua parcialidade como tal.

$\mathrm{O}$ último texto aqui analisado refere-se a um período posterior e nada menciona sobre os judeus, aqui o foco parece ser realmente a crítica ao imperador do momento. Trata-se dos Acta Appiani, um grande texto que está substancialmente completo, apresentando poucas lacunas. Se comparado aos documentos citados acima, seu estado de preservação favorável nos permite ler com mais tranquilidade, ter maior controle da narrativa e, por isso, entender melhor o contexto. A escrita do relato foi atribuída à primeira metade do séc. III e o episódio se situa no reinado de Cômodo, consequentemente o período de escrita é mais próximo do evento que narra, comparado aos documentos citados acima. Os Acta Appiani narram o julgamento de Apião, aparentemente já condenado 
à morte, mas que ainda tenta ser ouvido pelo imperador e reforçar algumas ideias. Chama a atenção nesse texto (mais que nos anteriores) o explícito tom abusivo e desafiante ao imperador, expresso na fala abertamente ofensiva de Apião. O documento é também importante por ser talvez a "ponte" que liga os outros escritos e ajuda a definir e agrupar essa literatura.

Trata-se então do último texto em escala cronológica e de contestação mais evidente a um imperador, Cômodo. Já na sua primeira fala, Apião faz uma grave acusação ao soberano de forma direta e sem rodeios; ele expõe ao imperador o problema da supervalorização que estaria ocorrendo com a exportação de trigo. César demonstra não entender do que Apião está falando e pergunta quem estaria recebendo esse dinheiro. $\mathrm{O}$ alexandrino não hesita e acusa o próprio Cômodo de estar recebendo, ou seja, acusa-o de estar tirando proveito dos lucros da importação romana de trigo do Egito. O príncipe parece não aceitar a denúncia e faz a pergunta para se certificar de uma grave acusação como essa estar sendo dirigida a ele. $\mathrm{O}$ alexandrino confessa não ter certeza, mas afirma ser este o boato que estava circulando, o que torna a denúncia ainda mais grave e desafiante, pois, mesmo sem certeza, Apião lança a acusação. Nesse momento, o diálogo é interrompido pelo pedido de Cômodo para levar o alexandrino à execução e o narrador entra em ação, acrescentando um conteúdo dramático ao episódio, dizendo que, no mesmo instante em que Apião estava sendo levado à execução, ele vê o corpo de um morto. A referência seria provavelmente a alguém morto pelas autoridades romanas e que poderia servir para realçar a crueldade e facilidade na realização das execuções pelo Império.

A continuidade do texto (no outro fragmento) começa com a fala de Apião perguntando a Heliodoro se ele nada faria ao vê-lo ser levado à execução. Este encoraja Apião a enfrentar a morte, com as seguintes palavras: (col. i, 1. 9-14) "Heliodoro disse: A quem poderemos falar, se não temos ninguém para escutar? Corra, meu filho, para a morte! A sua glória será morrer pela sua cidade nativa mais querida. Não fique angustiado!" ${ }^{47}$ Esse pedaço tem o intuito de glorificar a sua morte; morrer em nome de Alexandria e por um ideal. No entanto, Apião precisa ser encorajado para enfrentá-la. Depois da exaltação de sua própria nobreza, o príncipe pergunta a Apião se ele sabe com quem está falando e este mais uma vez o desafia, com a seguinte fala:

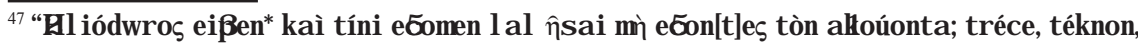

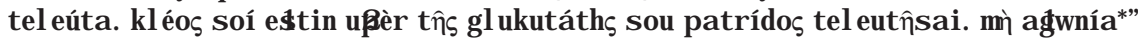


(col. ii, 1. 4-13) Apião: "Eu tenho conhecimento, Apião está diante de um tirano".

O imperador: "[Não], mas um rei”.

Apião: "Não diga nada! Pois seu pai, o divino Antônio, era adequado para ser imperador. Escute: primeiramente ele era filósofo, em segundo lugar ele não era avarento, em terceiro, ele era bondoso. Mas você tem justamente as características opostas: você é tirano, desonesto e grosseiro!",48

Nesse trecho, parece ser usado um artifício retórico, já que o imperador dirige a pergunta a Apião e este se aproveita para dizer o que já estaria planejando. Cômodo mais uma vez afirma sua autoridade e posição de poder, mas Apião insiste nas suas ofensas e retoma novamente o que estava dizendo do príncipe da forma mais clara e direta. Este chama novamente o executor pelo contínuo tom abusivo de Apião que ainda faz um último pedido. Pelos elogios ao antecessor de Cômodo (seu pai Marco Aurélio), tem-se a impressão de que a crítica de Apião não é generalizada contra o poder imperial, mas especificamente contra aquele reinado.

Depois de sucessivos embates com o príncipe, Apião suplica que possa ao menos ser executado com suas roupas nobres (provavelmente a vestimenta dos membros do Ginásio), o que o imperador concede. Nesse momento, o objetivo parecer ser o de realçar a nobreza do alexandrino, para que ficasse para a posteridade. Com o intuito de ter seu pedido aceito, o alexandrino volta a se dirigir ao César num tom respeitoso.

Segue uma nota narrativa carregada de dramaticidade: (col. iii, 1. 5-11) "Apião pegou a sua faixa e a colocou na cabeça, e ao colocar os sapatos brancos em seus pés, ele se lamentou no meio de Roma: 'Corram, romanos, e contemplem um espetáculo único, um alexandrino ginasiarca e embaixador sendo levado à execução!" "49 Aqui o autor aproveita para propagar várias ideias: a insensatez do imperador e a falta de clemência do poder romano e, também, a importante posição da cidade e dos membros do ginásio. Tal objetivo fica mais nítido ao descrever a perplexidade dos romanos presentes no cenário. Com isso, o tre-

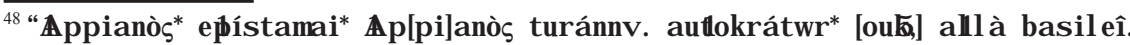

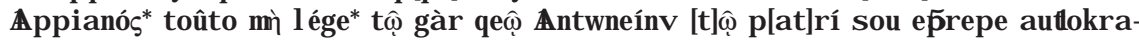

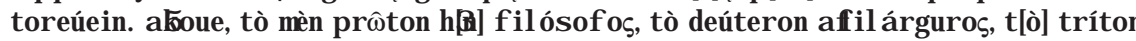
filágagos*soi toútwn tà eøantía ebkeitai, turannía a li ilokagaqía a paidía."

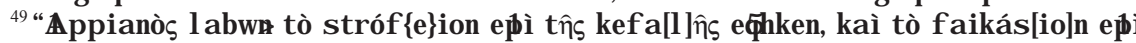

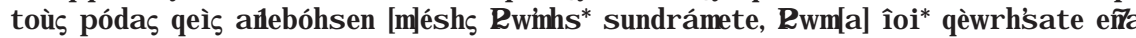
a $\mathbb{p}$ la i đonos a pagóm[eno]n gumnasíarcon kaì presbeutìn $\mathbb{A}$ I exandréwn."
} 
cho destaca a falta de legitimidade das atitudes do imperador mesmo entre os romanos, já que a morte de um alexandrino os teria comovido também.

O imperador manda Apião ser trazido de volta e este responde de forma visivelmente dramática: (col. iv, 1. 3-8) "Quem foi que me chamou agora quando eu estava novamente me direcionando para a morte e ao encontro daqueles que morreram antes de mim, Theon, Isidoro e Lampo? Foi o Senado ou você, seu chefe de brigada?" ${ }^{50} \mathrm{O}$ trecho tem um forte apelo dramático. Além disso, é o único texto dos aqui analisados que faz referência a personagens alexandrinos de julgamentos anteriores. Theon, Isidoro e Lampo são relembrados como exemplos de coragem e honra e também como provas da falta de clemência da lei romana. Esse pedaço pode ser a chave que liga esse escrito aos anteriores e os caracteriza, senão como gênero, ao menos como documentos que se articulam de alguma forma e tinham um ideal e público comuns. Pretende-se ilustrar também a união do grupo alexandrino, por meio de todos os condenados pelo Império.

Na sequência, o imperador afirma estar acostumado a castigar aqueles que tinham perdido a noção do respeito e o desafiavam, como era o caso de Apião. Provavelmente sua fala se refere também aos outros alexandrinos condenados pelos romanos, todos devidamente castigados pelos atos desrespeitosos e desafiadores. Prossegue a discussão e Apião responde novamente mencionando o seu status:

(col. iv, 1.13-15, col. v, 1.1-14) Apião: "Em nome da sua sorte, eu não estou enfurecido e nem perdi a noção, mas quero me pronunciar em nome da minha nobreza e de [meus privilégios]".

O imperador: "[E quais são?]."

Apião: "De categoria nobre e ginasiarca".

O imperador: "Então [afirmas] que eu não tenho destaque?"

[Apião: "Isso] eu não sei; eu estou apenas reportando em nome da minha própria nobreza e privilégios".

[O imperador]: "Você não sabe então que...?"

Apião: "Se você realmente não souber a [verdade], eu te informarei. [Primeiramente, [César] salvou Cleópatra ... teve controle do império e, como alguns [dizem], tomou posse..."

O imperador recebe as considerações de Apião como ofensa, pois enfatizando sua posição nobre ele poderia estar sugerindo a ausência de nobreza do

\footnotetext{
50"tích ale tòn deúterón mou ộdhn proskunoûnta kaì toùs prò emoû tel euths anta s, Q éw-

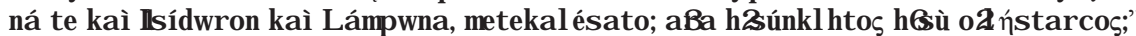
51 "Appianós* nì tìn sìn túchn oube maínomai oube a ponenóhmai, all lupèr tîs
} 
príncipe. Pode tratar-se de mais um artifício retórico, já que o autor coloca na boca do imperador coisas que Apião não disse, como se o príncipe percebesse a denúncia do alexandrino antes mesmo de acusá-lo diretamente.

É curiosa a menção a César e Cleópatra no final do texto. Talvez o alexandrino estivesse lembrando o imperador da proeminência que a elite da cidade deveria ter diante dele, devido à aproximação entre César e Cleópatra. Pois, a partir daí, Alexandria teria sempre importante posição dentre os imperadores. Outra possibilidade nesse trecho é o intuito de evidenciar novamente, mesmo de maneira sutil, a ignorância do imperador, daí a alusão ao episódio de César e Cleópatra. Ou seja, Apião informaria o imperador sobre o "começo de tudo", sobre o momento decisivo na história alexandrina. Nesse sentido, é Apião, alexandrino e ginasiarca, a fonte de saber do imperador. Em suma: pretende-se destacar sua ignorância até sobre assuntos "chaves" do Império e isso seria feito em oposição à sabedoria do alexandrino.

Após a análise dos documentos selecionados, finalizaremos com algumas considerações sobre as questões mais ilustrativas para a nossa proposta, para assim, organizarmos algumas sugestões sobre a natureza dessa literatura e sobre o que teria provocado seu surgimento. Vimos que a ênfase na categoria nobre dos membros do Ginásio é visível em inúmeras partes dos escritos trabalhados. É também recorrente o destaque à importância do cargo vinculado à valorização e exaltação de Alexandria. Fica expressa, nos trechos citados, a tentativa de se circunscrever uma identidade alexandrina a mais restrita possível, privilégio apenas de um seleto grupo de nativos da cidade que dispunham da mesma herança cultural nobre. A partir de uma definição desse grupo, exaltase a força e importância da cidade, concedidas por Alexandre, de quem seria a fiel herdeira. Percebe-se, nos textos, que os habitantes da cidade sempre se referem a si mesmos como alexandrinos. Ou seja, mais do que reforçar a herança grega, pretende-se exaltar a cidade e seus cidadãos proeminentes. Esta herança era intrínseca e constitutiva de sua cultura que já tinha sua força e identidade próprias, daí também o importante papel concedido a Serápis como a divindade

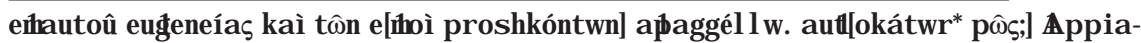

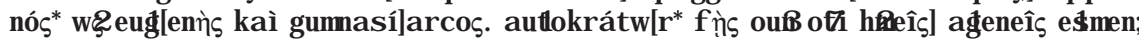

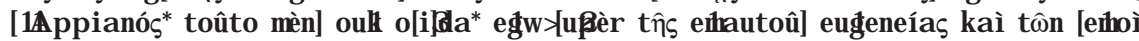
proshkón]twn a paggél I [w. a utlokrátwn*] nûn oul oi đasoti [ C. \& IA p pianós* toûto

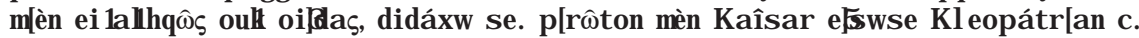
0] elkráths en Basi[l eía s, kaì wz l égou]s í tines, edla neí[s a to c.8]".
} 
legitimadora dessa cultura. Tal identidade seria reforçada para que os alexandrinos marcassem sua posição diante dos romanos e para denunciar os abusos dos judeus como cidadãos não-legítimos de Alexandria que, portanto, só estariam causando problemas e não poderiam ter os mesmos direitos dos alexandrinos.

Percebemos que, em alguns escritos, a postura antijudaica é mais nítida que a insatisfação em relação ao Império. No entanto, também pode ser vista como evidência de indignação indireta ao poder romano, referente a mudanças sociais ocorridas na cidade sob os novos dirigentes. É importante ressaltar, ainda, que as críticas dos alexandrinos a romanos e judeus tinham raízes e finalidades diferentes, daí serem observáveis também paralelamente. Claro que, sendo os romanos os que ditavam as regras e pela força que representavam, a repulsa a eles era ativa e desafiante, mas também respeitosa.

No que se refere às falas atribuídas aos personagens, podemos perceber que, apesar de os imperadores estarem sempre presentes nos diálogos e se cobrarem deles atitudes e resoluções para os problemas de Alexandria, em comparação ao espaço concedido à fala dos alexandrinos, os príncipes se mencionam pouco. Além disso, quando a voz é dada aos imperadores, suas palavras acabam geralmente levantando questões que são realmente centrais nos textos e se pretende enfatizar. Em alguns momentos, suas falas parecem servir apenas para destacar algo que os alexandrinos queriam mesmo salientar, ou ainda, deixar a "brecha" para que eles mesmos pudessem elaborar alguns assuntos. Por vezes, basta uma pergunta do imperador para levantar justamente os pontos que os alexandrinos pretendiam rebater. É possível que esse artifício fosse usado para atribuir, aos próprios romanos, considerações centrais, para não tornar a fala dos alexandrinos exaustiva, o que poderia tornar os textos declaradamente panfletários e, consequentemente, teriam menos legitimidade. Nesse sentido, a presença dos líderes pode servir para dar peso e legitimidade aos documentos, como se, através dos imperadores, os alexandrinos pudessem se fazer ouvir com mais facilidade, já que a presença do soberano denotaria a importância e alcance das petições e reclamações dos alexandrinos.

Mesmo nas falas mais breves e aparentemente objetivas dos imperadores, notam-se alguns detalhes de argumentação que parecem estar ali "incluídos" apenas para favorecer e tornar mais fácil as considerações do lado alexandrino. Tal objetivo fica expresso nos trechos enriquecidos retoricamente. Neles, observam-se elementos com o ideal perceptível de convencer o leitor, através da construção de diálogos e argumentações mais elaboradas. Outro aspecto 
também característico da forma de construção dos textos é a recorrência de detalhes que concedem dramatização aos episódios, principalmente nas falas atribuídas aos alexandrinos e nas notas narrativas.

Diálogos construídos em discurso direto têm comumente a intenção de deixar o leitor se posicionar. Mas nas fontes aqui trabalhadas, através da inclusão de notas narrativas e do predomínio das falas atribuídas aos alexandrinos, o objetivo de conduzir o leitor para o seu lado é visível. De qualquer maneira, esse modo de construção dos diálogos pretendia-se menos "partidário" e levaria o leitor para o lado alexandrino mais disfarcadamente, pois pela fala dos próprios personagens o leitor poderia formar sua opinião. A situação ambígua e o trato geralmente cordial com o imperador poderiam servir para disfarçar a insatisfação, já que os autores dos textos ainda tinham compromissos com os romanos e, caso fossem acusados, teriam formas de se defender e mostrar que não estavam escrevendo contra eles.

Percebe-se que, nos documentos, o Império está personificado na figura do imperador. Seu papel como juiz de todas as comunidades que conviviam em Alexandria é bem realçado. Ele é visto como o "centralizador" das necessidades dos provinciais, a quem deveriam dirigir suas queixas e cobranças. É dele que se esperam soluções para os problemas enfrentados pelos alexandrinos e mesmo quando se pretende alguma crítica em maior escala às estratégias mais gerais do poder romano ou reclamações contra oficiais específicos, nada se compara à força de sua liderança e a sua possibilidade de tudo controlar. E como ele era realmente a representação máxima do poder romano, criticá-lo e questionar suas atitudes, além de dirigir ofensas pessoais a ele, já representam o intuito de resistir ao Império e propagar alguma reação.

Em muitos casos as críticas são dirigidas a elementos isolados do Império ou a imperadores específicos. No entanto, na maioria dos textos, estão ausentes os nomes dos príncipes (o que em muitos casos dificulta a contextualização mais precisa dos escritos) e de outras autoridades romanas criticadas. Isso contrasta com os nomes dos alexandrinos que estão sempre presentes. Tal fato pode sugerir que a ideia era a propaganda mais geral, devido ao cuidado de não se explicitarem os alvos exatos das acusações. O mais importante era a contestação a determinados artifícios do poderio imperial, daí não ser necessário explicitar os objetos de crítica.

Percebe-se, nos relatos, que os alexandrinos do Ginásio demonstravam uma percepção ambígua do poder romano. O dilema era: aliar-se-iam a eles e manteriam sua posição privilegiada, mas, ao mesmo tempo, seriam condescendentes com 
suas formas de governar; ou encontrariam meios de se contrapor a eles, correndo o risco de ter seu status alterado, além de comprometer a posição proeminente do grupo. Nossa sugestão é que essa "indecisão" pode ter sido a reação inicial dos alexandrinos ao novo poderio e, diante da dúvida, o comando imperial estaria continuamente sendo avaliado de modo cuidadoso e observado por eles, para compreender o que se esperar dele e analisar até que ponto uma reação seria válida.

Como a romanização tinha várias formas de se impor, os modos de reagir também se expressavam de formas diversas. Ou seja, apesar de os alexandrinos terem se beneficiado com a nova liderança, eles também tinham suas formas de se manifestar e resistir, mesmo sem grandes intenções de subverter a ordenação mais ampla do poderio romano. Assim, o fato de fazer esse tipo de opinião circular por escrito demonstra a intenção desses grupos de expandir seu descontentamento e a difusão de ideias era um meio comum de revelar insatisfações. Os textos visavam, aparentemente, propagar ideias e se expandir em círculos reduzidos. Observa-se, entretanto, uma forma de "resistência textual" ao poderio romano que, mesmo sem ter alcançado grande repercussão ou ideal "subversivo", não deve ser desconsiderada. Nesse sentido, mesmo que o conteúdo dos textos tenha caráter literário, apenas o seu ideal de expandir insatisfações nesse contexto já é algo muito expressivo. Em suma: acreditamos que o importante era destacar a situação contemporânea dos alexandrinos para, a partir daí, tentar criar uma conscientização social e política na região, estimulando a problematização do presente com o intuito de denunciar questões atuais e complexas.

Não devemos, contudo, exagerar a dimensão da popularização e o alcance dos textos, já que nos faltam elementos para tal conclusão. Acreditamos que a divulgação foi moderada e acessível a um círculo restrito, pois se tivesse sido algo realmente grandioso, teríamos ao menos alguma menção direta dos textos em outras fontes do período ou posteriores, o que não ocorre. Ou seja, se tivesse sido uma propaganda em larga escala, teria tido alguma repercussão nos escritos da época, que resultasse ao menos em algum comentário ao "fenômeno propagandístico".

Mas, qual teria sido o ímpeto inicial para a escrita dos textos? Sugerimos que o primeiro passo para a origem dos escritos tenha surgido da mera intenção dos alexandrinos do Ginásio de reunir os registros oriundos de suas articulações com os representantes imperiais. Documentos que poderiam, oportunamente, servir para questionar acontecimentos pontuais na relação da cidade com os romanos. Num segundo momento, as polêmicas com a comunidade judaica podem ter servido de estímulo para intensificar ainda mais o questionamento quanto às inova- 
ções impostas. É provável, então, que a documentação seja resultado de uma onda de questionamento dos membros do ginásio e fruto do ambiente de discussão ali formado. Ou seja, inicialmente, a sua escrita não foi algo deliberado e nem surgiu de um ímpeto momentâneo. Foi derivada, portanto, do amadurecimento das reclamações e dos anseios dos alexandrinos. Embora sua divulgação tenha sido algo pensado, a aparição dos textos foi progressiva e inicialmente despretensiosa.

Os cidadãos do Ginásio podem ter começado a reunir os escritos para formar uma espécie de arquivo da cidade e, no clima de questionamento ali criado, começaram a reunir tais registros e elaborar cópias de documentos oficiais a que tinham acesso. A partir daí, começaram a utilizar tais textos, copiá-los e refiná-los para que pudessem servir para a posteridade, como uma espécie de "memorial do Ginásio Alexandrino". Fizeram isso utilizando-se de sua vivência política e das "armas" que tinham ao seu dispor (erudição, treinamento em retórica, dramaticidade, experiência política e bom conhecimento a respeito de Alexandria). "Sofisticavam" os relatos com base nos episódios vividos por alguns de seus membros diante de oficiais romanos, com o intuito de manifestar denúncias pontuais sobre determinadas ocorrências. Ou seja, acreditamos que o "elo" de união dos escritos, o elemento que os aproxima, seria o projeto dos alexandrinos configurado em longo prazo (no decorrer de dois séculos), por um mesmo grupo responsável pela liderança do Ginásio.

Acreditamos que a decisão para a divulgação da documentação de fato resultou do contexto de maior insatisfação dos alexandrinos com o Império que se manifestou com força e ficou mais nítido entre o final do séc. II e o início do III. ${ }^{52}$ Nesse momento, então, seriam retomados episódios anteriores vividos por

\footnotetext{
${ }^{52}$ Nos séculos I e II, a repressão dos romanos às manifestações de resistência ao Império era mais rígida, pela expansão não ter se encerrado, além da consolidação do poder romano em algumas áreas ser ainda frágil. Nesse sentido, a "censura" contra quem ameaçasse a estabilidade de opiniões era dura. Huzar argumenta que, aos poucos, Alexandria "perde o seu brilho" e autonomia e começa a "existir prioritariamente para servir o seu mestre". Ver: HUZAR, Eleanor G., op. cit., "Alexandria", p. 668. Sobretudo no séc. II d.C., isso ficou mais nítido, pois além da maior decadência cultural do período, há sinais de que o enriquecimento estava ficando mais lento. MILNE, Grafton, op. cit., 1924, p. 56-57. No séc. III, as atitudes repressivas diminuíram e, consequentemente, as críticas ao poder romano passaram a ser mais toleradas. Ver: MACMULLEN, Ramsay. Enemies of the Roman order. London; New York: Routledge, 1992, p. 156. Rostovtzeff realça que a política romana de promover a urbanização em cidades de pouco desenvolvimento cívico fez com que as capitais dos nomos começassem a se destacar também através de instituições tipicamente gregas. Tal situação fez com que Alexandria já não tivesse tanto destaque em relação às outras cidades do Egito, e nem tanta influência diante dos imperadores. Por isso, a insatisfação ao Império se torna mais comum. Salienta que "a nova realidade" era sentida pelos alexandrinos como sinal de decadência em re-
} 
aquele grupo para relatar seus anseios e reforçar a sua adesão, sua história e seu orgulho de pertencimento a Alexandria; sentimentos que poderiam estar fragilizados em decorrência de inúmeras imposições dos romanos e por problemas pontuais vivenciados por seus cidadãos. Ou seja, esse pode ter sido o período mais apropriado para manifestar algum tipo de reação às práticas imperiais, pois, além de todas as circunstâncias já realçadas acima, havia mais facilidade de expor insatisfações aos novos líderes. O séc. III se caracteriza, ainda, por um momento de maior "incremento" na burocracia das províncias e por uma crise generalizada no Império (econômica e política). ${ }^{53}$

Em suma, nossa sugestão é que a divulgação dos textos teria tido um fim geral de crítica aos romanos, embora o seu surgimento tenha sido pontual e específico. Nesse sentido, acreditamos que esse fim geral é o eixo de união dos escritos que se configurou pouco a pouco, ou seja, é o fator que caracteriza os textos como um "grupo documental". No entanto, não se devem esquecer as especificidades que geraram os documentos num primeiro momento e que conferem a cada um deles sua unicidade. A base que lhes deu origem foi específica, pois surgiram de episódios isolados e foram adaptados para atenderem a projetos comuns: o de servir de crítica e contestação ao poder imperial e reforçar a identidade e unidade do grupo do Ginásio através da exaltação ao grupo e a Alexandria. Pretendia-se, com isso, uma restrita circulação para criar uma conscientização nesse meio, embora o alcance espacial dos textos tenha sido considerável, como vimos pelos diferentes locais em que os fragmentos foram encontrados.

Todos os elementos ressaltados acima concedem a tais escritos alexandrinos um grande valor histórico, pois mesmo que alguns dos relatos tenham sido deli-

lação à antiga posição de relevo de Alexandria, já que ela se assemelharia cada vez mais a outros centros urbanos que estavam emergindo. Ver: ROSTOVTZEFF, Michael I., op. cit., 1937, p. 244. ${ }^{53}$ Ver: BELL, Harold I., op. cit., 1948, p. 193. Mais um episódio pode ter estimulado o intuito de criticar os romanos nesse período e ter sido recebido como uma espécie de "gota d'água" que desagradou a população frente aos dirigentes. Trata-se do massacre dos alexandrinos por Caracala que ocorreu em 215 (o episódio é narrado por HERODIANO. História, 4.8-9 e DION CÁSSIO. História romana 78. 22-24). O motivo teria sido algum episódio de ridicularização do imperador promovido na cidade, devido à sua "mania" de se comparar a Alexandre, além de sátiras que foram produzidas sobre a morte de seu irmão. Relata-se que a destruição na cidade foi ampla, e as medidas que o príncipe teria instituído após os problemas se estenderam à cidade como um todo (tropas permanentes de vigília na cidade, abolição de órgãos públicos etc.). Convencido de que a intelectualidade da cidade estava por trás da rebelião, Caracala interrompe também o patrocínio imperial que ainda era investido no Museu, diminuindo ainda mais a imigração de homens ilustrados para a cidade, fazendo com que a efervescência de sua vida intelectual enfraquecesse consideravelmente. 
beradamente elaborados, ou, no limite, relatem episódios ilusórios e fictícios, os anseios e o "motor" para sua produção são muito significativos. Nesse sentido, os pequenos fragmentos de papiro iluminam diversos pontos a respeito de questões cívicas de Alexandria e permitem investigar as polêmicas vivenciadas pelos seus cidadãos e diferentes grupos sociais no contexto de sujeição ao Império.

\section{Referências bibliográficas}

\section{Documentos}

DION CÁSSIO. História romana. 9 vols. Tradução de Earnest Cary e Herbert B. Foster. Harvard: Loeb Classical Library, 1925-1995.

EUSÉBIO. História eclesiástica. 2 vols. Tradução de Kirsopp Lake e J. E. L Oulton. Harvard: Loeb Classical Library, 1926-1932.

FÍLON. In Flaccum. Tradução de F. H. Colson. Harvard: Loeb Classical Library, 1941-1995. FÍLON. Legatione ad Gaium. Tradução de F. H. Colson. Harvard: Loeb Classical Library, 1962- 1991.

FLÁVIO JOSEFO. Guerra dos judeus. 3 vols. Tradução de H. ST. J. Thackeray. Harvard: Loeb Classical Library, 1926-1997.

FLÁVIO JOSEFO. Antiguidades judaicas. 8 vols. Vários tradutores. Harvard: Loeb Classical Library. 1930-1965.

HERODIANO. História. 2 vols. Tradução de C. R. Whittaker. Harvard: Loeb Classical Library, 1969-1995.

MUSURILLO, Herbert. Acts of the pagan martyrs (textos e comentários). New York: Oxford University Press, 1954

Select Papyri. Vol. II. Non-literary papyri. Public documents. Tradução de A. S. Hunt e C. C. Edgar. Harvard: Loeb Classical Library, 1934-1956.

\section{Bibliografia}

BAGNALL, Roger S. Reading papyri, writing ancient history. London; New York: Routledge, 1995.

BARCLAY, John. Jews in the Mediterranean Diaspora: From Alexander to Trajan (323 B.C.E. - 117 C.E.). Berkeley; Los Angeles; London: University of California Press, 1996.

BELL, Harold I. The problem of the Alexandrian Senate. In: Aegyptus, 12, 1932, p. 173-184.

BELL, Harold I. Alexandria ad Aegyptum. In: The Journal of Roman Studies, 36, 1946, p. 130-132.

BELL, Harold I. Egypt from Alexander the Great to the Arab conquest. Oxford: Claredon Press, 1948. 
BOWMAN, Alan K.; RATHBONE, Dominic. Cities and administration in Roman Egypt. In: Journal of Roman Studies, 82, 1992.

BOWMAN, Alan K. Egypt after the Pharaos 332 B.C. - A.D. 642. California: University of California Press, 1986.

BRUNT, Peter A. The administrators of Roman Egypt. Journal of Roman Studies, 65, 1975, p. 124-47.

COLLINS, John J. Between Athens and Jerusalem: Jewish identity in the Hellenistic Diaspora. Michigan: Eerdmans, 2000.

DAVIS, Simon. Race-relations in Ancient Egypt: Greek, Egyptian, Hebrew, Roman. London: Methuen \& Co., 1951.

DELIA, Diana. Alexandrian citizenship during the Roman Principate. Atlanta: Scholars Press, 1991.

EL-ABBADI, Mostafa. The Alexandrian citizenship. In: Journal of Egyptian Archaeology, 48, 1962, p. 106-23.

FRASER, Peter M. Ptolemaic Alexandria I-III. Oxford: Clarendon Press, 1972, p. 38 e 53.

GOODMAN, Martin. The Roman world. 44 B.C. - A.D. 180. London; New York: Routledge, 1997.

GREENBERG, Mark; HAMMA, Kenneth; GILMAN, Benedicte; MOORE, Nancy (eds.). Alexandria and alexandrinism: Papers delivered at a symposium organized by the J. Paul Getty Museum and The Getty Center for the History of Art and Humanities and held at the Museum April 22-25, 1993. Malibu, California: The J. Paul Getty Museum, 1996.

GRIMAL, Pierre. O Império romano. Lisboa: Edições 70, 1993.

HARRIS, William V.; RUFFINI, Giovanni (eds.). Ancient Alexandria between Egypt and Greece. Leiden; Boston: Brill, 2004.

HUZAR, Eleanor G. Alexandria ad Aegyptum in the Julio-Claudian Age. In: HAASE, Wolfgang; TEMPORINI, Hildegard. (eds.) Aufstieg und Niedergang der Römischen Welt II.10.1. Berlin; New York: Walter de Gruyter, 1988, p. 619-668.

HUZAR, Eleanor G. Augustus, Heir of the Ptolemies. In: HAASE, Wolfgang; TEMPORINI, Hildegard. (eds.) Aufstieg und Niedergang der Römischen Welt II.10.1. Berlin; New York: Walter de Gruyter, 1988, p. 343-382.

JACOB, Christian; POLIGNAC, François de (eds.). Alexandria, third century $B C$ : The knowledge of the world in a single city. Alexandria: Harpocrates Publishing, 2000.

JONES, Stuart. Claudius and the Jewish question at Alexandria. In: Journal of Roman Studies, 16, 1926, p. 17-35.

LEWIS, Naphtali. Life in Egypt under Roman rule. Oxford; New York: Oxford University Press, 1983. 
LEWIS, Naphtali. Greeks in Ptolomaic Egypt: Case studies in the social history of the Hellenistic World. Oakville, Connecticut: American Society of Papyrologists, 2001.

MACMULLEN, Ramsay. Enemies of the Roman order. London; New York: Routledge, 1992.

MARLOWE, John. The Golden Age of Alexandria. London: Victor Gollancz, 1971.

MILLAR, Fergus. The emperor in the Roman world: 31 B.C. - A.D. 337. London: Duckworth, 1977.

MILNE, Grafton. A history of Egypt under Roman rule. London: Methuen \& Co., 1924.

MOMIGLIANO, Arnaldo. Os limites da helenização: A interação cultural das civilizações grega, romana, céltica, judaica e persa. Rio de Janeiro: Jorge Zahar, 1991.

MUSURILLO, Herbert. Acts of the pagan martyrs. New York: Oxford University Press, 1954.

ROSTOVTZEFF, Michael I. Historia social y económica del Império romano. Tomo primeiro. Madrid: Espasa-Calpe, S.A., 1937.

SARTRE, Maurice. El Oriente romano. Provincias y sociedades provinciales del Mediterráneo oriental: De Augusto a los Severos (31 a.C. - 235 d.C.). Madrid: Akal Ediciones, 1994.

STEEN, Gareth L. (ed.) Alexandria: The site and the history. New York; London: New York University Press, 1993.

TAKACS, Sarolta. A. Alexandria in Rome. In: Harvard Studies in Classical Philology, 97, 1995, p. $263-276$.

Recebido: agosto/2008 - Aprovado: junho/2009. 